\title{
1 Dissolution of Nontronite in Chloride Brines and Implications for the Aqueous
}

\section{History of Mars}

3 M.H. Steiner ${ }^{1}$, E.M. Hausrath ${ }^{1, *}$, M.E. Elwood Madden ${ }^{2}$, O. Tschauner ${ }^{1}$,B.L. Ehlmann ${ }^{3}$, $4 \quad$ A.A. Olsen ${ }^{4}$, S.R. Gainey ${ }^{1}$, and J.S. Smith ${ }^{5}$.

$6{ }^{1}$ Department of Geoscience, University of Nevada, Las Vegas 4505 S. Maryland

7 Parkway, Las Vegas, NV 89154-4010.

$8{ }^{2}$ School of Geology and Geophysics, University of Oklahoma, 100 E Boyd, Suite 710,

$9 \quad$ Norman, OK 73019.

$10{ }^{3}$ Division of Planetary Science, California Institute of Technology, 1200 East California

11 Boulevard Pasadena, CA 91125

$12{ }^{4}$ Department of Earth Sciences, University of Maine, 5790 Bryand Global Sciences

13 Center, Orono, ME 04469

$14{ }^{5}$ HPCAT, Geophysical Laboratory, Carnegie Institution of Washington, Argonne, IL

$15 \quad 60439$

16 *To whom correspondence should be addressed: Elisabeth.Hausrath@unlv.edu, (ph) 702-

$17 \quad 895-1134$ (f) 702-894-4064

18 Abstract:

19 Increasing evidence suggests the presence of recent liquid water, including

20 brines, on Mars. Brines have therefore likely impacted clay minerals such as the Fe-

21 rich mineral nontronite found in martian ancient terrains. To interpret these

22 interactions, we conducted batch experiments to measure the apparent dissolution

23 rate constant of nontronite at $25.0^{\circ} \mathrm{C}$ at activities of water $\left(a \mathrm{H}_{2} \mathrm{O}\right)$ of $1.00(0.01 \mathrm{M}$ 
$24 \mathrm{CaCl}_{2}$ or $\mathrm{NaCl}$ ), 0.75 (saturated $\mathrm{NaCl}$ or $\left.3.00 \mathrm{~mol} \mathrm{~kg}^{-1} \mathrm{CaCl}_{2}\right)$, and $0.50\left(5.00 \mathrm{~mol} \mathrm{~kg}^{-1}\right.$

$\left.25 \mathrm{CaCl}_{2}\right)$. Experiments at $a \mathrm{H}_{2} \mathrm{O}=1\left(0.01 \mathrm{M} \mathrm{CaCl}_{2}\right)$ were also conducted at $4 .{ }^{\circ} \mathrm{C}, 25.0$

$26{ }^{\circ} \mathrm{C}$, and $45.0^{\circ} \mathrm{C}$ to measure an apparent activation energy for the dissolution of

27 nontronite.

28 Apparent dissolution rate constants at $25.0^{\circ} \mathrm{C}$ in $\mathrm{CaCl}_{2}$-containing solutions

29 decrease with decreasing activity of water as follows: $1.18 \times 10^{-12} \pm 9 \times 10^{-14}$ moles

30 mineral m${ }^{-2} \mathrm{~s}^{-1}\left(a \mathrm{H}_{2} \mathrm{O}=1\right)>2.36 \times 10^{-13} \pm 3.1 \times 10^{-14}$ moles mineral m${ }^{-2} \mathrm{~s}^{-1}\left(a \mathrm{H}_{2} \mathrm{O}=\right.$

$310.75)>2.05 \times 10^{-14} \pm 2.9 \times 10^{-15}$ moles mineral $\mathrm{m}^{-2} \mathrm{~s}^{-1}\left(a \mathrm{H}_{2} \mathrm{O}=0.50\right)$. Similar results

32 were observed at $25.0^{\circ} \mathrm{C}$ in $\mathrm{NaCl}$-containing solutions : $1.89 \times 10^{-12} \pm 1 \times 10^{-13}$ moles

33 mineral m $\mathrm{m}^{-2} \mathrm{~s}^{-1}\left(a \mathrm{H}_{2} \mathrm{O}=1\right)>1.98 \times 10^{-13} \pm 2.3 \times 10^{-14}$ moles mineral m-2 $\mathrm{s}^{-1}\left(a \mathrm{H}_{2} \mathrm{O}=\right.$

34 0.75). This decrease in apparent dissolution rate constants with decreasing activity

35 of water follows a relationship of the form: $\log k_{d i s s}=3.70 \pm 0.20 \times a \mathrm{H}_{2} \mathrm{O}-15.49$,

36 where $k_{\text {diss }}$ is the apparent dissolution rate constant, and $a \mathrm{H}_{2} \mathrm{O}$ is the activity of

37 water. The slope of this relationship $(3.70 \pm 0.20)$ is within uncertainty of that of

38 other minerals where the relationship between dissolution rates and activity of

39 water has been tested, including forsteritic olivine $\left(\log R=3.27 \pm 0.91 \times a \mathrm{H}_{2} \mathrm{O}\right.$ -

4011.00 ) (OLSEN et al., 2015)and jarosite $\left(\log R=3.85 \pm 0.43 \times a H_{2} \mathrm{O}-12.84\right)$ (DiXon et

41 al., 2015), where $R$ is the mineral dissolution rate. This result allows prediction of

42 mineral dissolution as a function of activity of water and suggests that with

43 decreasing activity of water, mineral dissolution will decrease due to the role of

44 water as a ligand in the reaction.

45 Apparent dissolution rate constants in the dilute $\mathrm{NaCl}$ solution $\left(1.89 \times 10^{-12} \pm\right.$

$461 \times 10^{-13}$ moles mineral $\mathrm{m}^{-2} \mathrm{~s}^{-1}$ ) are slightly greater than those in the dilute $\mathrm{CaCl}_{2}$ 
47 solutions $\left(1.18 \times 10^{-12} \pm 9 \times 10^{-14}\right.$ moles mineral $\left.\mathrm{m}^{-2} \mathrm{~s}^{-1}\right)$. We attribute this effect to

48 the exchange of Na with $\mathrm{Ca}$ in the nontronite interlayer. An apparent activation

49 energy of $54.6 \pm 1.0 \mathrm{~kJ} / \mathrm{mol}$ was calculated from apparent dissolution rate constants

50 in dilute $\mathrm{CaCl}_{2}$ - containing solutions at temperatures of $4.0^{\circ} \mathrm{C}, 25.0^{\circ} \mathrm{C}$, and $45.0^{\circ} \mathrm{C}$ :

$512.33 \times 10^{-13} \pm 1.3 \times 10^{-14}$ moles mineral $\mathrm{m}^{-2} \mathrm{~s}^{-1}\left(4.0^{\circ} \mathrm{C}\right), 1.18 \times 10^{-12} \pm 9 \times 10^{-14}$ moles

52 mineral m-2 $\mathrm{s}^{-1}\left(25.0^{\circ} \mathrm{C}\right)$, and $4.98 \times 10^{-12} \pm 3.8 \times 10^{-13}$ moles mineral m $\mathrm{m}^{-2} \mathrm{~s}^{-1}\left(45.0^{\circ} \mathrm{C}\right)$.

53 The greatly decreased dissolution of nontronite in brines and at low

54 temperatures suggests that any martian nontronite found to be perceptibly

55 weathered may have experienced very long periods of water-rock interaction with

56 brines at the low temperatures prevalent on Mars, with important implications for

57 the paleoclimate and long-term potential habitability of Mars.

58 1. Introduction:

59 Liquid water is a necessary ingredient for life on Earth and its history on

60 Mars is therefore essential to understanding the potential habitability of that planet.

61 High ionic strength solutions like brines (up to $\sim 6.15 \mathrm{~m}$ ) are also able to host life at

62 a wide range of temperature and water activities (JONES AND LINEWEAVER, 2010).

63 While current surface conditions on Mars are not able to sustain pure liquid water,

64 brines may exist temporarily (HENDERSON-SELLERS AND MEADOws, 1976; BRASS, 1980;

65 HABERLE et al., 2001; JonEs AND LinEWEAVER, 2010; McEwEn et al., 2011; CHEvRIER AND

66 Rivera-VAlentin, 2012; MarTín-Torres et al., 2015; OjHa et al., 2015). Chloride and

67 chloride plus sulfate brines could be stable at present day temperatures on Mars

68 (BRASS, 1980) and increasing evidence points to their presence. Recurring Slope

69 Lineae (RSL) growth observed by the Mars Reconnaissance Orbiter are attributed to 
70 seasonal flow suggestive of liquid brines (MCEwEn et al., 2011; MARTínEZ AND RENNo,

71 2013; OjHA et al., 2015). Correlation of $\mathrm{Mg}$ with $\mathrm{S}$ and enrichment of $\mathrm{S}, \mathrm{Cl}$, and $\mathrm{Br}$

72 measured by the MER Spirit at Gusev Crater suggest transport by saline solutions

73 through soils (HASKIN et al., 2005; WANG et al., 2006; MING et al., 2008). Relative

74 humidity and temperature measurements from the Rover Environmental

75 Monitoring Station on the Curiosity Rover have also detected conditions capable of

76 supporting perchlorate brines (MARTíN-TORRES et al., 2015), and perchlorate

77 measurements at the Phoenix landing site suggest thin films of perchlorate solutions

78 (Cull et al., 2010). Ice excavated by the Phoenix Lander has been argued to have

79 formed from a frozen brine because of its relative softness (RENNó et al., 2009; SMITH

80 et al., 2009). Obliquity-driven climate change is proposed to have deposited then

81 removed ice over large swaths of the Martian surface, and periodically made liquid

82 water more available (WORDSWORTH, 2016). Therefore, over the course of martian

83 history even long after the inferred wetter epochs ending $\sim 3.5 \mathrm{Ga}$, a significant

84 proportion of the exposed land surface may have been affected by interaction with

85 small quantities of liquid water, and that water is likely to have been a brine.

86 The Fe-rich smectite nontronite has been detected on the surface of Mars,

87 particularly in ancient terrains (PoulET et al., 2005). Nontronite has been found

88 intimately mixed with sulfates at Gale Crater (MILLIKEN et al., 2010; THOMSON et al.,

89 2011) and it has also been found beneath Al-rich silicates at Mawrth Vallis (BIBRING

90 et al., 2006; BISHOP et al., 2008; WRAY et al., 2008; MCKEOWN et al., 2009; LOIZEAU et

91 al., 2010; Noe DobreA et al., 2010), at Nili Fossae (EHLmAnN et al., 2009); Valles

92 Marineris (RoACH et al., 2010); and Terra Sirenum (Wray et al., 2011). Fe-Mg-rich 
93 phyllosilicates have also been documented in multiple locations on the surface of

94 Mars by the Compact Reconnaissance Imaging Spectrometer for Mars (CRISM) on

95 the Mars Reconnaissance Orbiter and the Observatoire pour la Minéralogie, l'Eau,

96 les Glaces et l'Activité (OMEGA) spectrometer on the Mars Express orbiters (PoulET

97 et al., 2005; BISHOP et al., 2008; MuSTARD et al., 2008; MURCHIE et al., 2009). If brines

98 have been active on the martian surface, it is likely that at least some of the

99 observed nontronite deposits have interacted with brines since their formation. A

100 key question is whether these ancient, nontronite-bearing terrains would record

101 evidence of such interaction.

102 Few studies have examined mineral dissolution rates in brines (HAUSRATH

103 And Brantley, 2010; Pritchett et al., 2012; Dixon et al., 2015; OlSEN et al., 2015), and

104 none that we know of have analyzed nontronite dissolution rates in brines. Previous

105 work suggests that mineral dissolution slows significantly in high-ionic strength

106 brines (HausRath And Brantley, 2010; Pritchett et al., 2012; Dixon et al., 2015;

107 OLSEN et al., 2015), and we therefore tested the importance of that effect on

108 nontronite, derived apparent dissolution rate constants, determined which

109 parameters influenced them, and calculated an apparent activation energy.

110 Apparent dissolution rate constants of nontronite were measured as a function of

111 activity of water $\left(a \mathrm{H}_{2} \mathrm{O}\right)$ at $a \mathrm{H}_{2} \mathrm{O}=1.00,0.75$ and 0.5 , and temperature at $4^{\circ}, 25^{\circ}$, and

$11245.0^{\circ} \mathrm{C}$. Experiments were performed at a $\mathrm{pH}$ of 2, chosen to be relevant to later,

113 colder and drier time periods, assumed to be acidic (BIBRING et al., 2006), when

114 brines are likely to have been important. Reacted material was examined to

115 determine the nature of alteration resulting from interaction with the brines. The 
116 results of this work can help interpret past aqueous conditions on Mars, thereby

117 providing a better understanding of the habitability of martian environments.

\section{2. Materials and Methods:}

\section{2.1 Materials:}

120 The Clay Mineral Society nontronite standard NAu-1 $\left(\mathrm{Na}_{1.05}\right)\left[\mathrm{Si}_{6.98}\right.$

$\left.121 \mathrm{Al}_{0.95} \mathrm{Fe}_{0.07}\right]\left[\mathrm{Al}_{0.36} \mathrm{Fe}_{3.61} \mathrm{Mg}_{0.04}\right]_{20} \mathrm{O}(\mathrm{OH})_{4}$ (GATES et al., 2002) was used in all mineral

122 dissolution experiments. NAu-1 was mined from the Uley Graphite Mine, Australia

123 (KeELING et al., 2000) and has been previously characterized as predominantly

124 nontronite with traces of kaolin, quartz, biotite and goethite totaling approximately

$12510 \%$ (KeELING et al., 2000). Naturally occurring clay minerals such as NAu-1

126 commonly include trace mineral phases which are very difficult to remove without

127 altering the main phase (MILLER et al., 2012). However, pure, synthetic clay minerals

128 produced in the laboratory may not be representative of bulk clays formed in

129 nature. Therefore, we chose to use the natural $\mathrm{NAu}-1$ nontronite standard to study

130 dissolution rates in this study both for direct comparison with previous work

131 (GAINEY et al., 2014), and as a natural analog for bulk clay mineral deposits which

132 have been observed on Mars. In order to analyze the trace phases in the nontronite

133 NAu-1 used in our experiments we performed synchrotron XRD analyses described

134 below in Section 2.4.

135 We gently hand-crushed the well-indurated NAu-1 bulk sample in small

136 batches in an agate mortar and pestle to produce 40-120 micron-sized aggregates

137 which were separated by sieving. We sonicated the 40-120 micron aggregates in

138 ethanol at two minute intervals to remove fine particles on the surfaces of the larger 
139 nontronite aggregates, thus minimizing the effects of fine grains and individual

140 particles on the initial reactive surface area within the experiment and ensuring that

141 all experiments had both similar initial mass and surface area of NAu-1 available for

142 reaction. Crushing, sieving, washing and ultrasonicating minerals prior to

143 dissolution in kinetic studies is a standard method of preparation used in previous

144 studies of clay mineral dissolution (Devidal et al., 1992; WIELAND AND STUMm, 1992;

145 GANOR et al., 1995) to control the surface area of the materials.

146 A significant decrease in fine particles was observed when aggregate surfaces

147 were examined by Scanning Electron Microscopy (SEM) using a JSM-5610 Scanning

148 Electron Microscope after washing, although occasional fine particles remained.

149 Surface area of the bulk material was determined using a Quantachrome NOVA

150 2000e Surface area and Pore Size Analyzer. Nontronite was outgassed under

151 vacuum at $50^{\circ} \mathrm{C}$ for 24 hours before measuring a six-point BET (Brunauer-Emmett-

152 Teller) nitrogen adsorption isotherm (BRUNAUER et al., 1938). Apparent dissolution

153 rate constants were normalized to the measured nontronite initial surface area

$154\left(30.9 \pm 1.5 \mathrm{~m}^{2} \mathrm{~g}^{-1}\right)$. It should be noted that nontronite is prone to swelling when in

155 water which could result in a different surface area compared to dry nontronite

156 (BERGAYA AND LAGALY, 2013). However, normalization to BET surface area is a

157 standard method very commonly used in previous experiments reporting clay

158 mineral dissolution rates (CARRoll-WebB AND WaLther, 1988; CARRoll and Walther,

159 1990; Chin AND Mills, 1991; Huertas et al., 1998; MetZ And GAnor, 2001; CAMA et al.,

160 2002; CAMA AND GANOR, 2006) and so we utilize it here to allow comparison of

161 dissolution rates between different minerals. We also provide dissolution rates 
162 normalized to mass (Table 1).

\subsection{Batch Dissolution Experiments:}

164 Experiments were designed to test the effect of water activity, solution

165 chemistry, and temperature on nontronite dissolution. Batch experiments were

166 performed using $\mathrm{CaCl}_{2}$ - and $\mathrm{NaCl}$-containing solutions with $a \mathrm{H}_{2} \mathrm{O}$ equal to $1.00,0.75$

167 and 0.5 , and 1.00 and 0.75 , respectively. The 1.00 dilute solutions contained $0.01 \mathrm{M}$

$168 \mathrm{NaCl}$ or $0.01 \mathrm{M} \mathrm{CaCl}_{2}$, which had an activity of water $=0.999$ calculated using

169 PHREEQC (PARKHURST AND APPELO, 1999), which is similar to terrestrial soil waters

170 (HARTER AND NAIDU, 2001). Dissolution experiments are commonly performed in low

171 ionic strength solutions rather than pure water to prevent rapid changes in the

172 activity of water as the mineral dissolves. The $0.75 a \mathrm{H}_{2} \mathrm{O} \mathrm{CaCl} 2$ brine was made by

173 adding $166.66 \mathrm{~g}$ of anhydrous $\mathrm{CaCl}_{2}$ to $500 \mathrm{~g}$ of $18.2 \mathrm{M} \Omega$ water, and the $0.50 a \mathrm{H}_{2} \mathrm{O}$

$174 \mathrm{CaCl}_{2}$ brine was made by adding $360.68 \mathrm{~g}$ of anhydrous $\mathrm{CaCl}_{2}$ to $500 \mathrm{~g}$ of $18.2 \mathrm{M} \Omega$

175 water (RARD AND CLEGG, 1997). The $\mathrm{NaCl}$ brine was made by adding $150 \mathrm{~g}$ of $\mathrm{NaCl}$ to

$176356 \mathrm{~g}$ of $18.2 \mathrm{M} \Omega$ water (CHIRIFE AND RESNIK, 1984).

177 All solutions were adjusted to an initial $\mathrm{pH}=2.0$ using high purity $\mathrm{HCl}$.

178 Previous measurements of $\mathrm{pH}$ in brines have employed multiple techniques, and

179 double junction fast flow pH electrodes have been commonly used (BOWEN AND

180 BENISON, 2009; HAUSRATH AND BRANTLEY, 2010). In order to compare apparent

181 dissolution rate constants across activities of water, it was necessary to ensure that

182 the initial $\mathrm{pH}$ was the same in all conditions. To do this, all $\mathrm{pH}$ measurements were

183 made with the same Mettler Toledo InLab® Expert Pro pH electrode. This electrode

184 has a double junction and temperature sensor, both of which increase accuracy 
185 when measuring $\mathrm{pH}$ in brines. We also measured the starting $\mathrm{pH}$ of the brines with a

186 VWR sympHony ${ }^{\mathrm{TM}}$ High-flow $\mathrm{pH}$ electrode designed for hard-to-measure samples

187 and measured values within $0.1 \mathrm{pH}$ units of the target $\mathrm{pH}$ of 2 . We therefore make

188 the assumption that although uncertainties on $\mathrm{pH}$ measurements are higher in

189 brines, these measurements are sufficiently precise to allow comparison between

190 activities of water and with previous data.

$191 \quad$ For each experimental condition except the $0.50 a \mathrm{H}_{2} \mathrm{O}$ experiments which

192 contained 5.0g of nontronite to increase solution concentrations, $0.5-1.0 \mathrm{~g}$ of

193 crushed, sieved and washed nontronite was combined with $200 \mathrm{ml}$ of solution in an

194 acid-washed Low Density Polyethylene (LDPE) batch reactor. To test the effect of

195 temperature and calculate an apparent activation energy of dissolution,

196 experiments were performed in $0.01 \mathrm{M} \mathrm{CaCl}_{2}$ solutions at $4.0^{\circ} \mathrm{C}, 25.0^{\circ} \mathrm{C}$, and $45.0^{\circ} \mathrm{C}$

197 on an orbital shaker in a temperature-controlled cold-room $\left(4.0 \pm 0.1^{\circ} \mathrm{C}\right)$, or in

198 temperature-controlled shaking water baths $\left(25.0 \pm 0.1^{\circ} \mathrm{C}\right.$ and $\left.45.0 \pm 0.1^{\circ} \mathrm{C}\right)$. All

199 solutions were equilibrated to the correct temperature for 24 hours prior to the

200 addition of nontronite. The experiments were agitated in a shaker bath to keep the

201 solution well-mixed and ensure that dissolution was not transport-limited. In all

202 cases, batch reactors were agitated at 100 strokes per minute.

203 To sample the reactors, ten ml of solution only (no mineral grains) were

204 removed at regular time intervals that varied depending on the temperature and

205 solution composition and were based on preliminary experiments. Because the

206 removal of the solution changed the water: mineral ratio throughout the

207 experiments, this changing ratio was accounted for after WELCH AND ULLMAN 
208 (2000)as described below. A minimum of 13 solution samples were collected

209 during the initial period of the experiments, and then batch reactors were allowed

210 to react for an additional 1-4 months to collect long term points under steady

211 conditions. Samples were taken at different time intervals to accommodate the different

212 dissolution rates. The $25^{\circ} \mathrm{C}$ and $45^{\circ} \mathrm{C}$ experiments were sampled $2-3$ times a day for one

213 week while the $4{ }^{\circ} \mathrm{C}$ experiments were sampled daily for three weeks. The $1.00 a \mathrm{H}_{2} \mathrm{O}$ and

$2140.75 a \mathrm{H}_{2} \mathrm{O}$ experiments were sampled 2-3 times a day for one week while the $0.50 a \mathrm{H}_{2} \mathrm{O}$

215 experiments were sampled daily for three weeks. The $\mathrm{pH}$ of each sample was measured

216 on a separate aliquot of unfiltered solution at room temperature, with the

217 remainder of the solution sample filtered through a $0.45 \mu \mathrm{m}$ polypropylene syringe

218 filter and acidified to $1 \% \mathrm{v} / \mathrm{v}$ with high purity $\mathrm{HNO}_{3}$. Each condition was run in

219 duplicate with at least one blank for each condition. A complete list of experimental

220 conditions, including duplicates, is shown in Table 1.

\subsection{Analytical Methods:}

222 Silica concentrations were measured with a Thermo Genesys 10S UV-Vis

223 spectrophotometer at a wavelength of either 700nm (dilute solutions and $\mathrm{NaCl}$

224 brines $)$ or $400 \mathrm{~nm}\left(\mathrm{CaCl}_{2}\right.$ brines $)$ using methods slightly modified from the ASTM

225 and USGS methods to optimize analysis in high ionic strength solutions (ASTM

226 D859-10; FISHMAN AND FRIEDMAN, 1989). The silica analysis consisted of two steps: 1)

227 the addition of an acid and ammonium molybdate to form silicomolybdate which

228 produces a yellow color, the intensity of which reflects the concentration of

229 available silica (ASTM D859-10) and 2) the reduction of silicomolybdate which

230 produces a blue color the intensity of which reflects the concentration of available 
231 silica (FISHMAN AND FRIEDMAN, 1989). Performing both steps increases the

232 measurement range to $0.1-100 \mathrm{ppm} \mathrm{SiO}_{2}$ measured at $700 \mathrm{~nm}$, compared to a

233 measurement range of $0.1-1.0 \mathrm{ppm} \mathrm{SiO}_{2}$ when only performing the first step

234 measured at 400nm (ASTM D859-10; GovETT, 1961). We used a hybrid method,

235 combining the first step from ASTM D859-10 and the second step from the USGS

236 test method I-1700-85 to avoid interference caused by precipitation of Ca sulfites

237 within the brines, which occurs during the second reducing step of the ASTM D859-

23810 method due to the addition of an amino-naphthol-sulfonic acid solution (ASTM

239 D859-10; FISHMAN AND FRIEDMAN, 1989). Both steps were used for samples from all

240 dilute experiments at all temperatures and $\mathrm{NaCl}$ brines with $a \mathrm{H}_{2} \mathrm{O}=0.75$. Only the

241 first step was used for $a \mathrm{H}_{2} \mathrm{O}=0.75 \mathrm{CaCl}_{2}$ and $a \mathrm{H}_{2} \mathrm{O}=0.50 \mathrm{CaCl}_{2}$ brines because

242 precipitation occurred when adding sodium sulfite as a reducing agent in step two.

243 In order to match the solution matrices for the standards and the samples,

244 standards were prepared in $18.2 \mathrm{M} \Omega$ water and then combined with a solution

245 matching the composition of the sample solution in a 1:1 ratio, and samples were

246 diluted 1:1 with $18.2 \mathrm{M} \Omega$ water. The average standard error of thirteen silica

247 calibration curves measured on the Thermo Genesys 10S UV-Vis spectrophotometer

248 was found to be $4 \pm 3 \%$, with the highest value $=8 \%$. Based on that, we assume a

249 conservative uncertainty of $10 \%$ on silica measurements.

250 The colorometric silicomolybdate method is commonly believed to measure

251 monomeric silica $\left(\mathrm{H}_{4} \mathrm{SiO}_{4}\right)$ (ICOPINI et al., 2005). ILER (1979) has argued that the

252 colorometric silicomolybdate method also measures concentrations of dimeric

$253\left(\mathrm{H}_{6} \mathrm{Si}_{2} \mathrm{O}_{7}\right)$, and possibly trimeric $\left(\mathrm{H}_{8} \mathrm{Si}_{3} \mathrm{O}_{10}\right)$ silica, and TANAKAA AND TAKAHASHIB 
254 (2001) have suggested that the method may also detect linear and cyclic tetramers.

255 Previous work has indicated that the rate of oligomerization from molybdate

256 reactive silica to silica nanoparticles or amorphous silica is slow under acidic

257 conditions such as those used here, as well as under low silica concentrations

258 (IcopINI et al, 2005). For example, IcopINI et al., (2005) observed very little

259 oligomerization at any $\mathrm{pH}$ in solutions of $4.2 \mathrm{mmol}$ silica, orders of magnitude above

260 the highest concentration of silica solutions measured in our brine experiments. In

261 previous work, silica concentrations in equilibrium with amorphous silica decreased

262 from an average of $3.76 \mathrm{mmol} \mathrm{SiO}_{2}$ in dilute solutions to $3.43 \mathrm{mmol} \mathrm{SiO}_{2}$ in the

263 presence of $\mathrm{Na}-\mathrm{K}-\mathrm{Ca}-\mathrm{Cl}-\mathrm{HCO}_{3}-\mathrm{H}_{2} \mathrm{O}$ solutions ranging from 0.01 molal to 0.24 molal

264 (ICOPINI et al., 2005). Forsterite, fayalite and basaltic glass dissolution in $\mathrm{Ca}-\mathrm{Na}-\mathrm{Cl}$

265 solutions also resulted in decreased steady silica concentrations at higher

266 concentrations, with steady concentrations in near eutectic brines at $22.1^{\circ} \mathrm{C}$ ranging

267 from 0.17 to $0.45 \mathrm{~mm}$ (HAUSRATH AND BRANTLEY, 2010). We therefore make the

268 assumption here that these measurements are representative of silica release from

269 the nontronite surfaces.

270 Iron concentrations were measured using a Thermo Scientific iCE 3000

271 series Atomic Absorption spectrometer for all samples for which sufficient solution

272 remained after silica measurements. All samples were treated with a $\mathrm{CaCO}_{3}$ solution

273 to reduce interference, following the method described by EATON et al. (2005).

274 Samples from experiments with $a \mathrm{H}_{2} \mathrm{O}=1.00$ were analyzed for iron concentrations

275 without dilution. Brine samples required a 1:8 dilution to prevent damage to the AA

276 spectrometer (PriTchETT et al., 2012). The detection limit for Fe concentrations was 
277 measured as $0.05 \mathrm{ppm}$ using the method described by the Perkin-Elmer Analytical

278 Methods for Atomic Absorption Spectroscopy manual (CORPORATION, 1964), resulting

279 in a practical quantitation limit of $0.20 \mathrm{ppm}$. Because solution samples were filtered 280 through a $0.45 \mu \mathrm{m}$ filter and then acidified, any iron-rich nanoparticles or colloids

281 that passed through the filter and then dissolved upon acidification would also have

282 been measured. However, low (non-stoichiometric) iron concentrations suggest

283 such nanoparticles or colloids did not contribute significantly to measured Fe

284 concentrations.

\section{2.4 Characterization of the solid:}

After collection of the long-term solution chemistry point(s) for each

287 experiment ( 3-6 months), solutions were decanted and the remaining material

288 was rinsed with $18.2 \mathrm{M} \Omega$ water. Rinsed reacted material was frozen for at least 24

289 hours, and then freeze dried for 24 hours to remove all ice. Reacted material and

290 unreacted NAu-1 for comparison were carbon coated, and observed using a JEOL

291 field-emission SEM JSM-6700F. Samples were also analyzed using Visible/Near-

292 Infrared (VNIR) and Infrared (IR) reflectance spectroscopy to further constrain

293 alteration and to be able to make a direct comparison to Mars. VNIR spectra were

294 measured over the range $0.4-2.5 \mu \mathrm{m}$ using an ASD FieldSpec3 and IR spectra were

295 measured over the range 2.5 to $25 \mu \mathrm{m}$ using a iS50 FTIR spectrometer with all

296 spectra measured at the California Institute of Technology. ENVI version 4.7 was

297 used to remove the continuum and to identify the absorption wavelengths. FE-SEM,

298 VNIR, and IR analysis also included reacted nontronite removed from a set of

299 experiments within a saturated $\mathrm{CaCl}_{2}$ brine. Those experiments provided sufficient 
300 reacted material for analysis but had aqueous Fe and Si concentrations below

301 detection for all solution samples and were not included in the kinetic portion of

302 this study.

303 Unreacted and reacted nontronite were also examined by synchrotron XRD.

304 Unreacted NAu-1 was measured at the synchrotron beamline 16-ID-B at the

305 Advanced Photon Source in transmission mode with a rotating sample and

306 collimated primary beam with a spot size of approximately $150 \times 150 \mu \mathrm{m}^{2}$. A Pilatus

307 1M area detector was used for data acquisition, and details on experimental set up

308 can be found in KunZ et al. (2005). The use of an unfocused beam allows analysis of

309 a larger area than a focused beam. NAu-1 reacted in the presence of $0.01 \mathrm{M} \mathrm{NaCl}$

310 was examined at the synchrotron beamline 12.2.2 at the Advanced Light Source

311 using a focused beam with a spot size of approximately $30 \times 40 \mu \mathrm{m}^{2}$. For the reacted

312 NAu-1, two grains were examined, one representative of the majority of the bulk

313 reacted material, and the other a whitish grain that was also common. In each case

314 samples were analyzed on capillary tubes.

\section{3. Results:}

\section{3.1 Solution chemistry:}

317 The $\mathrm{pH}$ of each experiment typically remained relatively steady, increasing

318 somewhat over time (see Supplemental Material). In general, experiments in dilute

319 solutions remained the most stable with measured pH values for $a \mathrm{H}_{2} \mathrm{O}=1.00$

320 conditions ranging from 1.98 to 2.08 at $4.0^{\circ} \mathrm{C}, 1.84$ to 2.54 at $25.0^{\circ} \mathrm{C}$, and 1.92 to

3212.43 at $45.0^{\circ} \mathrm{C}$. Experiments performed in lower water activity solutions had larger 
322 changes, with measured pH values for $a \mathrm{H}_{2} \mathrm{O}=0.75$ ranging from 1.90 to 3.05 and

$323 a \mathrm{H}_{2} \mathrm{O}=0.5$ ranging from 1.78 to 2.6 (see Supplemental Material).

324 Moles released of silica and iron were corrected for solution volume removed

325 during sampling and therefore changing water: mineral ratios after WELCH AND

326 ULLMAN (2000):

$$
m_{(t)}=m_{(t-1)}+\left(c_{(t)}-c_{(t-1)}\right) V_{(t-1)} \quad \text { (Eq. 1) }
$$

328 where $m_{(t)}$ and $m_{(t-1)}$ are moles of silica or iron released to solution at time $t$ and $t-1$

329 (the preceding time interval), $c_{(t)}$ and $c_{(t-1)}$ are the concentrations of silica or iron in

330 moles $\bullet$ liter ${ }^{-1}$ at time intervals $t$ and $t-1$, and $V$ is the volume of solution in liters

331 remaining at time $t-1$.

332 Silica concentrations in samples collected during the initial period of the

333 experiments showed a non-linear relationship with time indicative of an approach

334 to steady state or equilibrium where an opposing precipitation reaction is important

335 (Supplementary Material figures 1-14).

336 All samples with sufficient solution remaining after measurement of silica

337 were analyzed for Fe concentrations but only experiments at $a \mathrm{H}_{2} \mathrm{O}=1.0 \mathrm{had}$

338 detectable concentrations. Similar to silica concentrations, Fe release increased

339 over time, approaching steady conditions (Supplemental Materials Figures 15-33).

340 In all cases, Fe: Si ratios in solution were below the Fe: Si ratio in nontronite,

341 indicating incongruent dissolution and/or precipitation of Fe-bearing phases in

342 experiments at $a \mathrm{H}_{2} \mathrm{O}=1.00$ (Figure 1). This is consistent with previous work (METZ

343 et al., 2005; GAINEY et al., 2014), which concluded that Fe is not released 
344 stoichiometrically during smectite dissolution because of preferential Fe

345 reabsorption and precipitation.

3.2 FE-SEM Results:

$348 \quad$ No observations by FE-SEM indicated significant alteration or secondary

349 mineral precipitation. Similar surfaces were observed in both reacted and unreacted

350 nontronite, with nontronite with rounded, rough edges being more common than

351 nontronite with smooth sharp surfaces. No observable difference with changing

352 activity of water and temperature was observed (Figure 2).

\section{3.3 IR Results:}

$354 \quad$ Changes in the VNIR spectra due to interaction with liquid water or brines

355 are slight if present (Figure 3). A slight shift shortward of about 10nm can be seen in

356 the $2.43 \mu \mathrm{m} \mathrm{Fe}-\mathrm{OH}$ absorption in samples exposed to saturated $\mathrm{CaCl}_{2}$ brines

357 compared to all other brine and dilute experiments. This shift could be explained by

358 an extra absorption caused by differences in water content, crystallinity or

359 occupancy of octahedral cation sites. VNIR spectra are, however, largely invariant.

FTIR spectra have more noticeable spectral changes. The Si-O stretch near

$3621000 \mathrm{~cm}^{-1}$ becomes narrower for all reacted samples. A reflectance

363 maximum/emission minimum at $1220 \mathrm{~cm}^{-1}$ and a feature at $790 \mathrm{~cm}^{-1}$ disappear in

364 reacted samples compared to the unreacted $\mathrm{NAu}-1$ spectra. The Al/Si-O-Si

365 deformations between 600 and $400 \mathrm{~cm}^{-1}$ change in shape for all $25.0^{\circ} \mathrm{C}$ and $45.0^{\circ} \mathrm{C}$

366 experiments. The spectra of the reacted samples are more typical of dioctohedral 
367 smectites (MICHALSKI et al., 2005) and some observed spectral changes could be

368 caused by the removal or transformation of the minor phases in NAu-1.

3693.4 Synchrotron XRD results:

370 Synchrotron XRD analyses of unreacted NAu-1 indicate the presence of bulk

371 nontronite along with small amounts of kaolinite, quartz, anatase and a $10 \AA ̊$ phase in the

372 glauconite-illite series (Figure 4a). This is consistent with previous analyses of NAu-1

373 indicating trace amounts of other phases (KEELING et al. 2000). Observations of

374 representative reacted NAu-1 indicate bulk nontronite along with goethite and the $10 \AA$

375 phase in the glauconite-illite series (Figure 4b). The $10 \AA$ phase in the glauconite-illite

376 series, and the biotite that has been previously detected in NAu-1 (KeELING et al., 2000)

377 are likely to be the same or very similar, given their similarity by X-ray diffraction. The

378 representative reacted nontronite also shows a shift in the 001 peak to lower angles,

379 possibly due to cation exchange between the $\mathrm{Ca}$ originally in the interlayer, and the $\mathrm{Na}$

380 present in solution, as well as an increase in peak width due to weathering of nontronite,

381 either due to a reduction in grainsize or intra-lattice (stacking) disorder. This is relevant

382 to smectites at Gale which also show a smaller basal spacing (VANIMAN 2014). The

383 goethite in the reacted material is fine scale, with an average grain size likely 100-300

$384 \mathrm{~nm}$.

385 Synchrotron XRD analyses did not detect anatase, kaolinite, or quartz in the

386 reacted sample, in contrast to the untreated nontronite. This could be due to either 1)

387 the inherent variability that comes with fine scale micro XRD analyses that sample a

388 very small volume of each aggregate of grains or 2) more significant dissolution of

389 these minerals relative to nontronite. The loss of anatase is consistent with the results of 
390 GAINEY et al. (2014) who showed steady state concentrations of Ti below detection. The

391 loss of quartz is also not surprising, due to the very crystalline nature of that mineral,

392 which means that very small concentrations can be detected by XRD. Due to the very

393 small concentrations of quartz, and the much higher surface area of the bulk nontronite,

394 we anticipate that the dissolution of quartz was minor relative to the dissolution of the

395 bulk nontronite. In addition, dissolution trends are consistent with previous observations

396 of dissolution of clay minerals, and not with what would be expected if dissolution of

397 quartz were an important factor, which is discussed below. Similarly, the small amounts

398 of kaolinite, and the fact that it has a significantly slower dissolution rate at the $\mathrm{pH}$ of our

399 experiments than nontronite (GAINEY et al., 2014) suggest that its dissolution was also

400 minor relative to the dissolution of the bulk nontronite. The detection of significant

401 goethite in the reacted material (Figure 4b) is consistent with the low stoichiometric

402 release of Fe relative to silica throughout the experiments (Figure 1), although goethite

403 has also previously been detected in unreacted NAu-1 (Keeling et al. 2000). We note,

404 however, that all of these trends are observed in the mineralogy of the material sampled

405 at the end of the experiment after the final, steady concentration measurement, rather

406 than throughout the experiment.

407 In a separate synchrotron experiment, a single whitish reacted NAu-1 grain which

408 was also observed to be common was examined by synchrotron-X-ray diffraction. The

409 obtained diffraction pattern indicates the presence of a highly disordered or

410 nanocrystalline phyllosilicate that can be interpreted as disordered nontronite (Figure 4c).

411 This observation suggests the potential dissolution of nontronite and reprecipitation of

412 disordered nontronite or a phase similar to it. 
414 Silicon occupies 90\% of the tetrahedral sites in nontronite (VELDE, 1995;

415 KEELing et al., 2000; GAinEY et al., 2014), and dissolution of the tetrahedral site is

416 assumed to represent the rate-limiting step in smectite dissolution (MARTY et al.,

417 2011). We therefore calculated apparent dissolution rate constants from silica 418 release.

419 Several approaches were followed to ensure that at least one steady point 420 was measured for all experiments. Unless steady conditions were obviously reached

421 during the first measured 13 points $\left(a \mathrm{H}_{2} \mathrm{O}=0.50\right.$ conditions only (see

422 Supplementary Material and Figures 5 and 6)), at least one point was measured

423 after a significantly longer time period (1-4 months) than the duration of the initial

424 experiments. For experiments in solutions with activity of water $=1.00$ and 0.75 ,

425 that point, or the average of multiple such points, was used as the steady condition

426 for calculation of apparent dissolution rate constants. For the $a \mathrm{H}_{2} \mathrm{O}=0.50$

427 experiments, steady conditions were defined as unchanged concentrations for three

428 or more days during the initial experiments, and the average of the last 5 points was

429 used as the steady value. The fact that steady conditions in the $a \mathrm{H}_{2} \mathrm{O}=0.50$ brines

430 were reached within the first 13 sampling points is not unexpected as silica

431 solubility is lower in brines than in dilute solutions and silica precipitation rates

432 increase with increasing ionic strength (ILER, 1979; ICOPINI et al., 2005).

433 In all cases but the experiments performed at $4.0^{\circ} \mathrm{C}$, silica release had clearly 434 approached steady conditions by the long-term point (Supplementary Material figures 435 1-14). In experiments performed at $4.0^{\circ} \mathrm{C}$, silica release less obviously reaches 
436 steady conditions. However, the measured silica concentrations display curvature

437 over time (Figure 5 and Supplementary Material), and since long term silica

438 concentrations at $4.0^{\circ} \mathrm{C}$ are only slightly lower than the long term points measured

439 at $25.0^{\circ} \mathrm{C}$ and $45.0^{\circ} \mathrm{C}$, they therefore likely represent a good estimate of steady

440 conditions.

441 The presence of steady conditions (Supplementary Material figures 1-14)

442 could be due to either steady state conditions, in which Si release from one phase is

443 equal to Si precipitation to another, or true chemical equilibrium with a Si-

444 containing phase, in this case, nontronite. In order to model either behavior, we

445 calculate the rate of change in moles of silica released at any time $(\mathrm{m})$ as resulting

446 from the apparent dissolution rate constant $\left(k_{\text {diss }}\right)$ multiplied by the surface area of

447 the primary mineral, $A\left(\mathrm{~m}^{2}\right)$, minus the loss due to precipitation, with $k_{p p n}\left(\mathrm{~s}^{-1}\right)$

448 defined as the precipitation rate constant of the secondary phase multiplied by the

449 moles released at any point ( $m$ ) (HAUSRATH and BRANTLEY 2010).

450

451

$$
\frac{d m}{d t}=A k_{d i s s}-k_{p p n} m .
$$

453

454 Manipulating this equation results in an equation that reduces at steady state to 455

$$
0=A k_{d i s s}\left(1-\frac{k_{p p n}}{A k_{d i s s}} m_{s s}\right),
$$


459 where $m_{s s}$ is moles released at steady state. Rewriting this equation to isolate $m_{s s}$

460 results in the following equation

461

462

$$
m_{s s}=\frac{A k_{d i s s}}{k_{p p n}} \text {, }
$$

464 where after substitution, separating variables and integrating, the resultant

465 equation can be used to calculate the apparent dissolution rate constant $\left(k_{\text {diss }}\right)$ if

466 moles released at any given time period, moles released at steady state, and surface

467 area are known (see HAUSRATH and BRANTLEY 2010 for more detail):

$$
-m_{s s} \ln \left(1-\frac{m}{m_{s s}}\right)=A k_{d i s s} t+C
$$

471 where $m$ is moles released of silica at each point calculated as described in equation

$4721, m_{s s}$ is moles released at steady state based on the long term point(s) measured

473 after 5-179 days as described above, $A$ is the surface area measured by BET analysis

474 as described above, $k_{\text {diss }}$ is the apparent dissolution rate constant in $\mathrm{mol} \mathrm{m}^{-2} \mathrm{~s}^{-1}$

475 calculated over the entire duration of dissolution, $t$ is time in seconds, and $C$ is the

476 constant of integration. The uncertainty on the apparent dissolution rate constant

477 was estimated from the standard error on the regression ( $\mathrm{mol} \mathrm{s}^{-1}$ ) with the $5 \%$

478 uncertainty of the BET surface area $\left(\mathrm{m}^{2}\right)$ propagated through, and divided by the

479 stoichiometric coefficient (6.98 mol Si per 1 mol nontronite). Apparent dissolution 
480 rate constants decreased with decreasing activity of water and temperature (Table

$481 \quad 1$; Figure 7 and 8).

482 An apparent activation energy was calculated by plotting the natural log of

483 the apparent dissolution rate constant versus $1000 / \mathrm{T}$, where $\mathrm{T}$ is the temperature

484 in K. The apparent activation energy is the negative slope of that line multiplied by

485 the universal gas constant $\left(8.31 \mathrm{~J} \mathrm{~K}^{-1} \mathrm{~mol}^{-1}\right)$. In these experiments, apparent

486 dissolution rate constants from batch reactors with $a \mathrm{H}_{2} \mathrm{O}=1.00$ containing $\mathrm{CaCl}_{2}$

487 were used to calculate an apparent activation energy (Figure 8) of $54.6 \pm 1.00$

$488 \mathrm{~kJ} / \mathrm{mol}$.

489 4. Discussion:

4904.1 The effect of brines on nontronite dissolution:

491 In these experiments, dissolution of nontronite was slower in lower water

492 activity brines than in dilute solutions (Figure 7). Apparent dissolution rate

493 constants of nontronite in $a \mathrm{H}_{2} \mathrm{O}=0.75 \mathrm{CaCl}_{2}$ solutions were 0.20 times as fast when

494 compared to apparent dissolution rate constants of nontronite in $a \mathrm{H}_{2} \mathrm{O}=1.00 \mathrm{CaCl}_{2}$

495 solutions, while apparent dissolution rate constants of nontronite in $a \mathrm{H}_{2} \mathrm{O}=0.50$

$496 \mathrm{CaCl}_{2}$ solutions were 0.017 times as fast when compared to apparent dissolution

497 rate constants in $a \mathrm{H}_{2} \mathrm{O}=1.00 \mathrm{CaCl}_{2}$ solutions. Apparent dissolution rate constants

498 for nontronite in $a \mathrm{H}_{2} \mathrm{O}=0.75 \mathrm{NaCl}$ solutions were 0.11 times as fast when compared

499 to apparent dissolution rate constants of nontronite in $a \mathrm{H}_{2} \mathrm{O}=1.00 \mathrm{NaCl}$ solutions.

500 Previous studies examining mineral dissolution rates in the presence of

501 brines have similarly shown that dissolution rates decrease with decreasing water

502 activity (HausRath AND Brantley, 2010; PritchetT et al., 2012; Dixon et al., 2015; 
503 OlSEN et al., 2015). HAUSRATH AND BRANTLEY (2010) documented a decrease in olivine

504 dissolution of an order of magnitude in $\mathrm{CaCl}_{2}-\mathrm{NaCl}-\mathrm{H}_{2} \mathrm{O}$ near-eutectic brines

505 compared to dilute solutions. OLSEN et al. (2015) suggested that dissolution rates of

506 forsteritic olivine are slowed in Mg-sulfate, Na-sulfate, Mg-nitrate, and K-nitrate

507 brines due to decreases in the available water participating as a ligand in the

508 dissolution reaction. PRITCHETT et al. (2012) documented a decrease in jarosite

509 dissolution rates in early experiments of almost two orders of magnitude in an $a \mathrm{H}_{2} \mathrm{O}$

$510=0.35$ brine compared to dilute solutions. The early decrease in jarosite dissolution

511 was then followed by an increase in jarosite dissolution rates following gypsum

512 precipitation allowing $\mathrm{Cl}^{-}$complexation, although rates were still slower than in

513 dilute solutions. Dixon et al. (2015), who performed batch jarosite dissolution

514 experiments similar to PRITCHETT et al. (2012) but also performed experiments in

515 flow-through reactors, confirmed the decreased dissolution rates in brines in

516 general, as well as the increase in jarosite dissolution rates in saturated calcium

517 chloride brines over time. Both OLSEN et al. (2015) and PRITCHETT et al. (2012) show

518 a linear decrease in log dissolution rates with decreasing activities of water.

519 Our results also show a linear decrease in log apparent dissolution rate

520 constants with decreasing activities of water, which is the same within uncertainty

521 as that measured by OLSEN et al. (2015) and PRITCHETT et al. (2012) (Figure 9).

522 Solutions used by OLSEN et al. (2015) at $\mathrm{pH}=2$ covered activities from 1.0 to 0.91 ,

523 and the slope of the decreasing log dissolution rates of forsteritic olivine with

524 decreasing activity of water was $3.27 \pm 0.91$. In PRITCHETT et al. (2012), dissolution

525 of jarosite was measured in $\mathrm{CaCl}_{2}$ and $\mathrm{NaCl}$ brines $\left(a \mathrm{H}_{2} \mathrm{O}=1.0-0.35\right)$ using ultrapure 
526 deionized water with a $\mathrm{pH}$ of $\sim 3-4$. These jarosite experiments showed a linear

527 decrease in log dissolution rates of jarosite with decreasing activity of water with a

528 slope of $3.85 \pm 0.43$ (Figure 9). Our results, which have a slope of the decreasing log

529 apparent dissolution rate constant of nontronite with decreasing activity of water of

$5303.70 \pm 0.20$, are within uncertainty of OLSEN et al. (2015) and PRITCHETT et al. (2012).

531 They are therefore also consistent with decreased activity of water decreasing

532 dissolution, likely due to the water acting as a ligand during nontronite dissolution

533 (OLSEN et al., 2015).

534 Apparent dissolution rate constants for nontronite in the $\mathrm{CaCl}_{2}$ and $\mathrm{NaCl}$

$535 a \mathrm{H}_{2} \mathrm{O}=0.75$ brines were within uncertainty of each other (Table 1), but apparent

536 dissolution rate constants in the $a \mathrm{H}_{2} \mathrm{O}=1.00 \mathrm{CaCl}_{2}$ solutions were 0.62 times as fast

537 as in the $a \mathrm{H}_{2} \mathrm{O}=1.00 \mathrm{NaCl}$ solution. Multiple factors could be contributing to the

538 difference between dissolution in the $0.01 \mathrm{M} \mathrm{NaCl}$ and $\mathrm{CaCl}_{2}$ solutions, including

539 differences in the ionic strength and the ions in the solution, as well as the identity

540 of the ions (Ca versus $\mathrm{Na}$ ) present within the interlayer of the clay mineral.

541 The $0.01 \mathrm{M}$ solutions of $\mathrm{CaCl}_{2}$ and $\mathrm{NaCl}$ have different ionic strengths $(0.01$

$542 \mathrm{~mol}$ for the $\mathrm{NaCl}$ solution and $0.02 \mathrm{~mol}$ for the $\mathrm{CaCl}_{2}$ solution calculated using

543 PHREEQC (PARKhuRST And ApPelo, 1999). Dove And Nix (1997) have shown that the

544 presence of cations enhanced dissolution of quartz by modifying rates of solvent

545 motion, exchange, or orientation at the mineral - solution interface at

546 concentrations that bracket those used in our $a \mathrm{H}_{2} \mathrm{O}=1.00$ experiments $(0.0001-0.2$

547 molal). However, they also showed that the effects of Ca and Na are approximately

548 equal. If the effect observed in these experiments were based solely on the ionic 
549 strength, then the difference between the ionic strengths of the two solutions would

550 likely cause enhanced dissolution in the $\mathrm{CaCl}_{2}$ solution. Since enhanced dissolution

551 is instead observed in the presence of the $\mathrm{NaCl}$ solution, the difference in ionic

552 strengths between the two solutions is likely not the controlling factor in the

553 differences in dissolution measured in $a \mathrm{H}_{2} \mathrm{O}=1.00$ solutions.

$554 \quad$ The exchange of the $\mathrm{Na}$ ion in solution with the Ca ion in the nontronite

555 interlayer is shown in the synchrotron microXRD results (Figure 4) where the

556 reacted nontronite has a 001 peak shifted to lower angles due to the smaller sodium

557 ion. This ion exchange may cause dissolution of nontronite to be faster in the

558 presence of solutions in which the ion in solution is different from that in the

559 interlayer. In previous work, MYLLYKYLÄ et al. (2013) performed dissolution

560 experiments of either $\mathrm{Na}$ - or Ca-containing montmorillonite in a low ionic strength

561 solution $(\mathrm{I}=0.005 \mathrm{~m})$ that contained $\sim 10 \mathrm{x}$ as many moles of $\mathrm{Na}$ as Ca. They

562 observed slightly enhanced dissolution of the Ca-containing montmorillonite over

563 the Na-containing montmorillonite at $25^{\circ} \mathrm{C}$. Since the solution they were using

564 contained predominantly Na ions, their results are similarly consistent with faster

565 dissolution of smectites when the interlayer cation differs from that in solution,

566 leading to ion exchange. This effect therefore likely explains the observations of our

567 low ionic strength experiments.

568 Dissolution of nontronite in dilute $0.01 \mathrm{M} \mathrm{CaCl}_{2}$ and $\mathrm{NaCl}$ solutions in our

569 batch reactors was faster than nontronite dissolution rates previously measured

570 using flow-through reactors at a similar pH (Figure 7) (GAINEY et al., 2014). The

571 nontronite used in the GAINEY et al. (2014) study was the same NAu-1 as the 
572 nontronite used in this study, with the same size fraction $(40-125 \mu \mathrm{m})$. However,

573 GAINEY et al. (2014) used the final surface area rather than the initial surface area

574 used in this study. When the GAINEY et al. (2014) rates are normalized to the initial

575 surface area of washed nontronite used in this study, flow-through dissolution rates

576 were approximately $0.11-0.35 \mathrm{x}$ as fast as the dissolution measured here (Figure 7).

577 This is consistent with previous studies which have shown that dissolution rates of

578 smectite measured in batch reactors were three times faster than smectite

579 dissolution rates in flow-through reactors (FURRER et al., 1993). The difference in

580 rates measured in batch and mixed flow reactors can be caused by different particle

581 aggregation as a result of the difference in mixing methods (FURRER et al., 1993). In

582 addition, GAINEY et al. (2014) calculated rates from the last five data points of each

583 steady state condition, whereas in this study we used the solution chemistry over

584 the entire duration of the experiments.

$585 \quad$ Both the apparent dissolution rate constants measured in this study as well

586 as the rates measured by GAINEY et al. (2014) are similar to previous measurements

587 of clay mineral dissolution rates in the literature (WIELAND AND STUMm, 1992; CAMA et

588 al., 2002; RoZALÉN et al., 2008). WIELAND AND STUMm (1992) measured dissolution

589 rates for kaolinite using Si release of $9.73 \times 10^{-13} \pm 1.1 \times 10^{-13} \mathrm{~mol} \mathrm{~m}^{-2} \mathrm{~s}^{-1}$ at a pH of 2.00

590 and CAMA et al. (2002) measured dissolution rates for kaolinite based on silica of

$5913.61 \times 10^{-14} \pm 5.8 \times 10^{-15} \mathrm{~mol} \mathrm{~m}^{-2} \mathrm{~s}^{-1}$ at $\mathrm{pH} 2.04$, both in flow-through reactors. RozALÉN

592 et al. (2008) measured a montmorillonite dissolution rate based on $\mathrm{Si}$ of 3.30x10-14

$593 \mathrm{~mol} \mathrm{~m}^{-2} \mathrm{~s}^{-1}($ error $<15 \%)$ at $\mathrm{pH}$ 1.98. Dissolution measured in our study was faster

594 than kaolinite dissolution measured by WiELAND AND STUmm (1992) and CAmA et al. 
595 (2002) and montmorillonite dissolution measured by RozALÉn et al. (2008). The

596 dissolution of nontronite is likely impacted by substitution occurring within the

597 mineral structure: increasing amounts of ferric Fe relative to $\mathrm{Al}$ in the octahedral

598 site is likely to decrease the solubility of the mineral based on previous

599 measurements that showed that the solubility of smectites decreased with the

600 composition of the octahedral layer in the following order: $\mathrm{Mg}>\mathrm{Fe}^{2+}>\mathrm{Al}>\mathrm{Fe}^{3+}$

601 (TARDY AND GARRELS, 1974; TARDY AND FRITZ, 1981). With substitution of Fe in the

602 tetrahedral layer, we anticipate that dissolution will increase due to the disruption

603 of the mineral structure (KOMADEL, 2003). However, this effect was not tested in this

604 study due to the use of only one mineral composition. Relative dissolution can also

605 be difficult to compare due to differences in experimental setup and surface area

606 measurements between laboratories.

607 The precipitation of a secondary phase similar to disordered nontronite during our

608 experiments is not surprising. Our experiments were intentionally run to steady

609 conditions (see Figures in SOM), and our kinetic modeling incorporates the increasingly

610 important back reaction (precipitation of a silica-containing phase) throughout the

611 experiments. The indication by synchrotron XRD that the proposed secondary phase is

612 disordered and nanocrystalline is also not surprising - it precipitated relatively rapidly

613 during our low temperature experiments, which would lead to a more disordered state. In

614 addition, the interactions between surface enthalpy and phase transformation energetics

615 mean that materials that would be metastable at larger grain sizes can be stabilized at the

616 nanophase (NAVROTSKY et al., 2008), which may have been important in stabilizing the

617 nanocrystalline material observed in our experiments. 
Although the presence of other trace phases with the bulk nontronite in NAu-1

619 detected by synchrotron analyses is not ideal, their presence does not affect the main

620 conclusion of this work, which is that decreases in the activity of water decrease the

621 dissolution rate in a very similar manner for very divergent minerals. As discussed

622 above, our results also do not show the effects that would be expected if dissolution of

623 trace phases were an important factor. We also note that although the use of synchrotron

624 microXRD is ideal for this purpose of potentially detecting small amounts of poorly

625 crystalline material present, it also is inherently not a bulk measurement, and therefore

626 captures variability at a very fine scale.

\section{4.2 Effect of Temperature and Activation Energy:}

629 Brines remain liquid at lower temperatures than dilute solutions, including

630 the low temperatures on present day Mars (BRASS, 1980; HABERLE et al., 2001).

631 Nontronite dissolution as a function of temperature is therefore relevant to

632 interpreting past aqueous interactions on Mars. Using apparent dissolution rate

633 constants measured in dilute $\mathrm{CaCl}_{2}$ solutions at $4.0^{\circ} \mathrm{C}, 25.0^{\circ} \mathrm{C}$, and $45.0^{\circ} \mathrm{C}$, an

634 apparent activation energy of $54.6 \pm 1.0 \mathrm{~kJ} / \mathrm{mol}$ was calculated. To the best of our

635 knowledge, this is the first measured activation energy for nontronite dissolution.

636 This apparent activation energy for nontronite dissolution is similar to

637 previously measured apparent activation energies for clay mineral dissolution.

638 Apparent activation energies for smectite dissolution have been reported as 87

$639 \mathrm{~kJ} / \mathrm{mol}$ (no error reported, although the error on the rate is reported at 15\%) for K-

640 montmorillonite when measured in flow-through and batch reactors over a pH 
641 range of 1.0-5.8 and a temperature range of $25^{\circ}-70^{\circ} \mathrm{C}($ RoZALÉN et al., 2008). AMRAM

642 AND GANOR (2005) measured an apparent activation energy of $71.1 \pm 8.4 \mathrm{~kJ} / \mathrm{mol}$ (for

643 a temperature range of $25^{\circ}-70^{\circ} \mathrm{C}$ ) for smectite. CAMA et al. (2002) report an

644 apparent activation energy of $78.4 \mathrm{~kJ} / \mathrm{mol}$ for kaolinite dissolution at $\mathrm{pH} 2.0$ in flow-

645 through reactors at temperatures ranging from $25^{\circ}-70^{\circ} \mathrm{C}$ (CAMA et al., 2002).

646 PALANDRI AND KHARAKA (2004) calculated an apparent activation energy of

647 dissolution of smectite of $23.6 \mathrm{~kJ} / \mathrm{mol}$, kaolinite of $65.9 \mathrm{~kJ} / \mathrm{mol}$ and montmorillonite

648 of $48.0 \mathrm{~kJ} / \mathrm{mol}$ using dissolution data from CARROLL AND WALTHER (1990); NAGY et al.

649 (1991); SOONG (1993); GANOR et al. (1995); HuERTAS et al. (1999a); HuERTAS et al.

650 (1999b) for kaolinite, NAGY (1995) for montmorillonite, and SVERDRUP (1990); ZYSSET

651 AND SCHINDLER (1996); BAUER AND BERGER (1998); HuERTAS et al. (2001) for smectite.

652 The activation energy measured in our experiments is also more consistent with the

653 activation energy of the mineral interface reaction $(\sim 60 \mathrm{~kJ} / \mathrm{mol})$ rather than the

654 activation energy of diffusion $(\sim 20 \mathrm{~kJ} / \mathrm{mol})$ (Brantley 2008), suggesting interface

655 control in our experiments.

6564.3 Implications for Mars:

657 Though evidence for clay mineral formation by extensive interaction with

658 liquid water early in Mars history is widespread, the low temperatures of the

659 present-day martian surface make aqueous alteration by brines the most probable

660 form of recent water-rock interaction on Mars. These brines could be habitable

661 environments. Although rare, life on Earth has been found at activities of water as

662 low as $0.61 \mathrm{in}$ a high-sugar food and also in saturated $\mathrm{NaCl}$ brines with an $a \mathrm{H}_{2} \mathrm{O}=$

6630.75 (GRANT, 2004). Gale Crater has been shown to have the potential for 
664 environmental conditions that keep perchlorate brines liquid (MARTíN-TORRES et al.,

665 2015). These brines would have temperatures and activities of water that are too

666 low to support terrestrial life, but areas with higher humidity and temperatures

667 could allow brines of other compositions to exist. $\mathrm{NaCl}$ and $\mathrm{CaCl}_{2}$ brines are

668 habitable on Earth and would be stable on Mars at higher temperatures and

669 humidities.

670 Dissolution of nontronite in high ionic strength solutions and at low

671 temperatures is significantly slower than in dilute solutions at room temperature,

672 suggesting that clay minerals reacted with brines on Mars may display much less

673 dissolution than clay minerals interacting with dilute solutions for the same

674 duration of time. In order to quantify this effect, using dissolution data from this

675 study and GAINEY et al. (2014), we have modeled nontronite dissolution under a

676 range of $\mathrm{pH}$, temperature, and activity of water conditions that are relevant to Mars

677 (Figure 10). Results indicate that dissolution of nontronite on Mars may be very

678 slow, and that the activity of water effect examined in this study has a larger impact

679 on dissolution than the temperature or $\mathrm{pH}$ range examined. Observable dissolution

680 of nontronite may therefore indicate potentially habitable conditions occurring on

681 Mars over very long timescales.

682 The indications of interaction with brines are subtle in collected data.

683 Infrared spectra show little to no systematic variability in the nontronite due to

684 treatment over the timescales of this study. XRD data do show a modest shift in the

685001 peak due to cation exchange in the interlayer. Thus, in a martian geologic unit,

686 nearby nontronite samples with different layer spacings may indicate interaction 
687 with brines of different fluid cation compositions at a later time in some locales.

688 Indeed, such 001 peak shifts have been found in inferred paleolake sediments at

689 Gale crater and attributed to variable interactions with later diagenetic fluids

690 (Vaniman et al., 2014).

691 An additional tracer of later alteration of nontronite might be the presence

692 of silica. Spectral evidence exists for widespread silica on the surface of Mars

693 (MICHALSKI et al., 2003) which has been attributed to surficial aqueous activity

694 (KRAFT et al., 2003). Martian silica coatings may be similar to coatings found on

695 Earth in cold and dry environments (DORN, 1998; DiXON et al., 2002; HAUSRATH et al.,

696 2008). Equilibrium with amorphous silica is reached faster and at lower

697 concentrations at lower activities of water (ICOPINI et al., 2005). The decreased

698 release of silica from the dissolution of nontronite over time in these experiments

699 could be due to the precipitation of amorphous silica, which has been detected in

700 previous dissolution experiments of nontronite (GAINEY et al., 2014). Precipitated

701 silica would be expected to form a silica-rich coating on the nontronite mineral

702 surfaces. On these samples, however, silica-rich coatings were not detected using

703 either FE-SEM,VNIR or FTIR spectroscopy, possibly due to the relatively short

704 duration of the experiments (85-179 days for the final time point), and the low total

705 amount of dissolution $(\sim 2-5 \%$ for dilute solutions at all temperatures, and $<1 \%$ for

706 all brines). FTIR observations show only subtle differences (Figure 3), likely due to

707 the alteration of trace phases.

708 Low Fe/Si ratios in solution samples (Figure 1) indicate that Fe is less mobile

709 than silica. Low iron release was also observed in nontronite dissolution by GAINEY 
710 et al. (2014) at pH 0.9 and 1.7. MetZ et al. (2005) observed lower than expected Fe

711 release compared to $\mathrm{Al}$ in smectite dissolution, which was caused by preferential Fe

712 reabsorption or precipitation. Our results may result from non-stoichiometric

713 dissolution, Fe sorption, or precipitation of Fe-bearing phases. A combination of

714 precipitated Fe-bearing phases and possible formation of reprecipitated disordered

715 nontronite (Figure 4) could also explain the similarities between reacted and

716 unreacted nontronite. XRD results suggest goethite formation, although goethite

717 has also been found in unreacted NAu-1 (KeELING et al., 2000). The breakdown of

718 iron silicates, including iron-bearing clays, by partial, low temperature alteration

719 has also been proposed to explain the ubiquity of nanophase Fe(III) oxides in

720 Martian dust eg (GoETz et al., 2005).

721

722 5. Conclusions:

723 A saturated $\mathrm{NaCl}$ brine with $a \mathrm{H}_{2} \mathrm{O}=0.75$, like the one used in this study, can

724 remain liquid down to $-21^{\circ} \mathrm{C}$ (BAUER et al., 1988) and has hosted life for a few

725 eukaryotes on Earth (GrANT, 2004). Environments on Mars that contain brines may

726 therefore be currently habitable environments.

727 Nontronite has been detected on the surface of Mars, particularly in ancient

728 terrains that have been exposed at the surface for billions of years (PoULET et al.,

729 2005; BiBRing et al., 2006; Bishop et al., 2008; EHLMANn et al., 2009; MiLLiKEn et al.,

730 2010; Thомson et al., 2011). To interpret interactions between nontronite and

731 potential solutions on Mars, we measured dissolution of nontronite in solutions 
732 with activities of water ranging from 1.00 to 0.50 and temperatures ranging from $7334.0^{\circ}-45.0^{\circ} \mathrm{C}$

$734 \quad$ Results indicate that nontronite dissolution decreases in brines with decreasing

735 activity of water, and that the relationship between log dissolution rates and the activity

736 of water in multiple brines $\left(\mathrm{NaCl}, \mathrm{CaCl}_{2}\right.$ and $\left.\mathrm{MgSO}_{4}\right)$ for multiple minerals (jarosite,

737 nontronite and olivine) is both linear and the same within uncertainty (OLSEN et al., 2015;

738 Dixon et al., 2015). This result strongly supports the proposed mechanism that water

739 behaves as a ligand during dissolution Cation exchange in the interlayer has been

740 shown to slightly increase dissolution in $a \mathrm{H}_{2} \mathrm{O}=1.00$ solutions. Nontronite

741 dissolution also decreased with decreasing temperature and an apparent activation

742 energy of $54.6 \pm 1.0 \mathrm{~kJ} / \mathrm{mol}$ was calculated, similar to other apparent activation

743 energies of smectite dissolution. Our results clearly demonstrate that nontronite

744 dissolves more slowly in the presence of brines than in dilute solutions. If evidence of

745 nontronite dissolution (such as nontronite depletion in a soil that had a nontronite-rich

746 parent material, for example) were observed on the martian surface, it would therefore

747 reflect a much great period of dissolution if the altering solutions were brines than if they

748 were dilute solutions. Deposits in which nontronite has been perceptibly leached may

749 therefore indicate potentially habitable conditions occurring over very long timescales on

750 Mars.

751 6. Acknowledgments

752 We would like to acknowledge the Mars Fundamental Research Program grant

753 NNX12AH96G, the UNLV Faculty Opportunity Award, and the UNLV Graduate and

754 Professional Student Association for travel funding. The authors would like to thank 
755 Chris Adcock, Kirellos Sefein, Valerie Tu, Renee Schofield, Courtney Bartlett, and

756 Angela Garcia for insightful conversation and lab assistance, and Minghua Ren and

757 Michael Strange for aid in FE-SEM imaging. Part of the work was conducted at the

758 HPCAT (Sector 16) of the Advanced Photon Source (APS), Argonne National

759 Laboratory and the 12.2.2 beamline of the Advanced Light Source. Use of the

760 Advanced Photon Source, an Office of Science User Facility operated for the U.S.

761 Department of Energy (DOE) Office of Science by Argonne National Laboratory, was

762 supported by the U.S. DOE under Contract No. DE-AC02-06CH11357. The Advanced

763 Light Source is supported by the Director, Office of Science, Office of Basic Energy

764 Sciences, of the U.S. Department of Energy under Contract No. DE-AC02-05CH11231.

765 ALS beamline 12.2.2 is partially supported by COMPRES, the Consortium for

766 Materials Properties Research in Earth Sciences under NSF Cooperative Agreement

767 EAR 11-57758. HPCAT operations are supported by DOE-NNSA under Award No.

768 DE-NA0001974 and DOE-BES under Award No. DE-FG02-99ER45775, with partial

769 instrumentation funding by NSF. We also appreciate thoughtful reviews by four

770 anonymous reviewers that greatly strengthened the paper. 
773 Figures and Tables

\section{Table 1. Apparent dissolution rate constants}

\begin{tabular}{|c|c|c|c|c|c|c|c|}
\hline $\begin{array}{l}\mathbf{T} \\
\left({ }^{\circ} \mathbf{C}\right)^{1}\end{array}$ & Salt & $a \mathrm{H}_{2} \mathrm{O}^{2}$ & $\begin{array}{l}\text { Duration } \\
\text { (days) }\end{array}$ & $\begin{array}{l}\mathbf{k}_{\text {diss }}(\mathrm{mol} \\
\left.\text { mineral } \mathbf{m}^{-2} \mathrm{~s}^{-1}\right)\end{array}$ & Uncertainty $^{3}$ & $\begin{array}{l}\mathbf{k}_{\text {diss }}(\mathrm{mol} \\
\left.\text { mineral g } \mathbf{g}^{-1} \mathrm{~s}^{-1}\right)\end{array}$ & Uncertainty $^{3}$ \\
\hline 25.0 & $\mathrm{CaCl}_{2}$ & 1.00 & 179 & $1.23 \times 10^{-12}$ & $1 \times 10^{-13}(8 \%)$ & $3.78 \times 10^{-11}$ & $2.2 \times 10^{-12}(6 \%)$ \\
\hline 25.0 & $\mathrm{CaCl}_{2}$ & 1.00 & 179 & $1.13 \times 10^{-12}$ & $9 \times 10^{-14}(8 \%)$ & $3.50 \times 10^{-11}$ & $2.2 \times 10^{-12}(6 \%)$ \\
\hline 25.0 & $\mathrm{CaCl}_{2}$ & 0.75 & 179 & $2.13 \times 10^{-13}$ & $3.2 \times 10^{-14}(15 \%)$ & $7.99 \times 10^{-12}$ & $9.1 \times 10^{-13}(8 \%)$ \\
\hline 25.0 & $\mathrm{CaCl}_{2}$ & 0.75 & 179 & $2.59 \times 10^{-13}$ & $2.9 \times 10^{-14}(11 \%)$ & $6.58 \times 10^{-12}$ & $8.4 \times 10^{-13}(8 \%)$ \\
\hline 25.0 & $\mathrm{CaCl}_{2}$ & 0.50 & 15 & $1.41 \times 10^{-14}$ & $1.7 \times 10^{-15}(12 \%)$ & $4.36 \times 10^{-13}$ & $4.8 \times 10^{-14}(8 \%)$ \\
\hline 25.0 & $\mathrm{NaCl}$ & 1.00 & 105 & $2.06 \times 10^{-12}$ & $1.0 \times 10^{-13}(5 \%)$ & $6.35 \times 10^{-11}$ & $5 \times 10^{-13}(8 \%)$ \\
\hline 25.0 & $\mathrm{NaCl}$ & 0.75 & 147 & $1.94 \times 10^{-13}$ & $2.4 \times 10^{-14}(12 \%)$ & $5.97 \times 10^{-12}$ & $5.8 \times 10^{-13}(8 \%)$ \\
\hline 25.0 & $\mathrm{NaCl}$ & 0.75 & 147 & $2.04 \times 10^{-13}$ & $3.5 \times 10^{-14}(17 \%)$ & $6.29 \times 10^{-12}$ & $6.7 \times 10^{-13}(8 \%)$ \\
\hline 45.0 & $\mathrm{CaCl}_{2}$ & 1.00 & 85 & $5.22 \times 10^{-12}$ & $3.8 \times 10^{-13}(7 \%)$ & $1.61 \times 10^{-10}$ & $9 \times 10^{-12}(8 \%)$ \\
\hline 45.0 & $\mathrm{CaCl}_{2}$ & 1.00 & 85 & $4.73 \times 10^{-12}$ & $3.9 \times 10^{-13}(8 \%)$ & $1.46 \times 10^{-10}$ & $9 \times 10^{-12}(8 \%)$ \\
\hline
\end{tabular}

$775{ }^{1}$ Temperature measured to $0.1^{\circ} \mathrm{C}$ using the internal thermometer on the water bath and cold-room.

$776{ }^{2} a \mathrm{H}_{2} \mathrm{O}$ from RARD AND ClEGG (1997) for $\mathrm{CaCl}_{2}$ brines, ChIRIFE AND RESNIK (1984) for NaCl brine, and calculated using PhreeqC

777 (PARKHURST AND APPELO (1999)) for all 0.01 M solutions.

778 3The uncertainty on the apparent dissolution rate constant was estimated from the standard error on the regression (mol s${ }^{-1}$ )

779 with the $5 \%$ uncertainty of the BET surface area $\left(\mathrm{m}^{2}\right)$ propagated through, and divided by the stoichiometric coefficient (6.98

780 mol Si per 1 mol nontronite)to obtain the uncertainty in mol mineral $\mathrm{m}^{-2} \mathrm{~s}^{-1}$. 


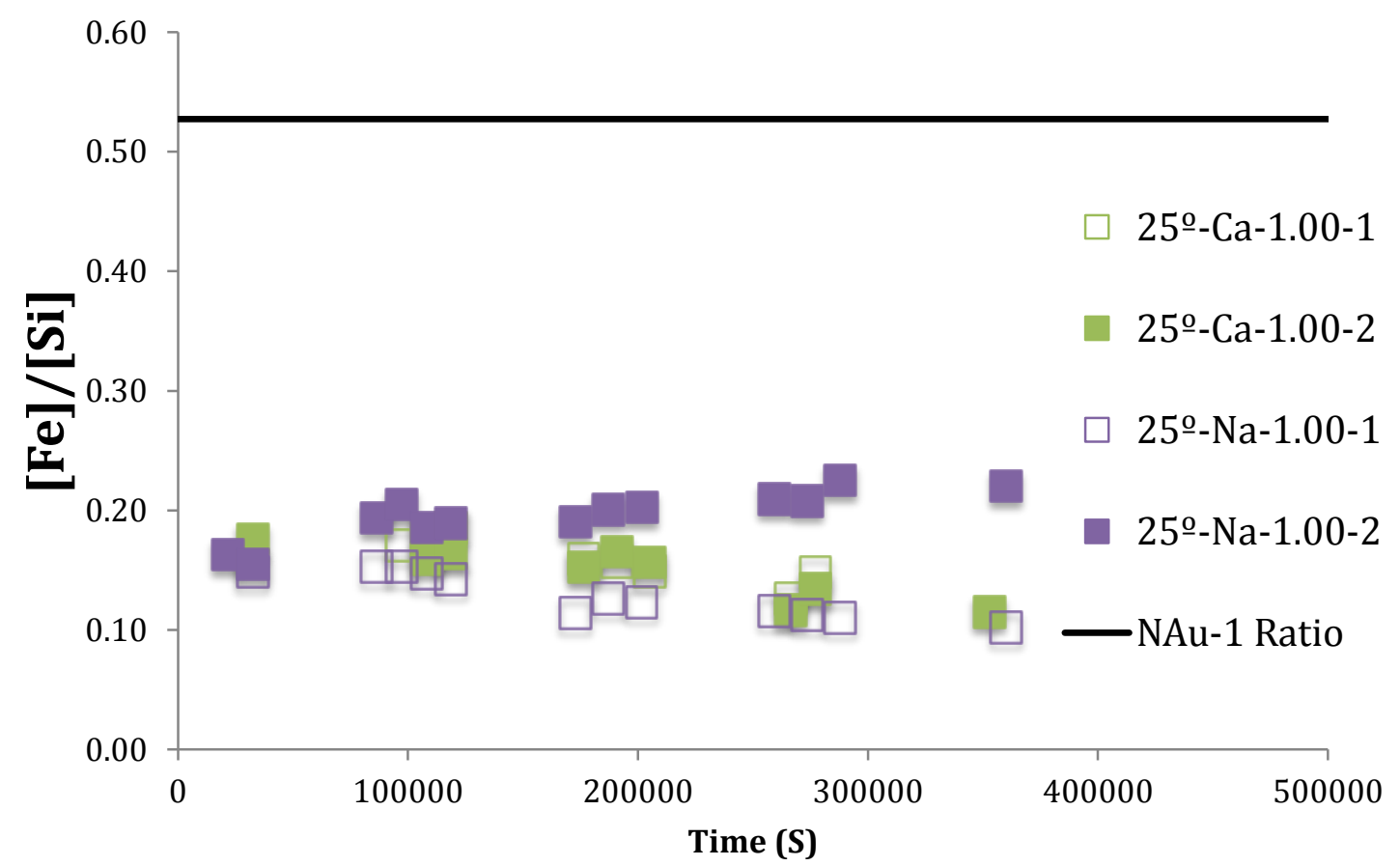

782

783

784 Figure 1. Fe: Si ratios for experiments at $25^{\circ} \mathrm{C}$ where [Fe] was above detection. The

785 solid line represents the stoichiometric ratio of Fe: $\mathrm{Si}$ in the unreacted nontronite $(0.52)$.

786 Experiments at $25{ }^{\circ} \mathrm{C}$ remain relatively stable near 0.20 over time. Analytical uncertainty on solution chemistry is smaller than all points.

788

789

790

791

792

793 

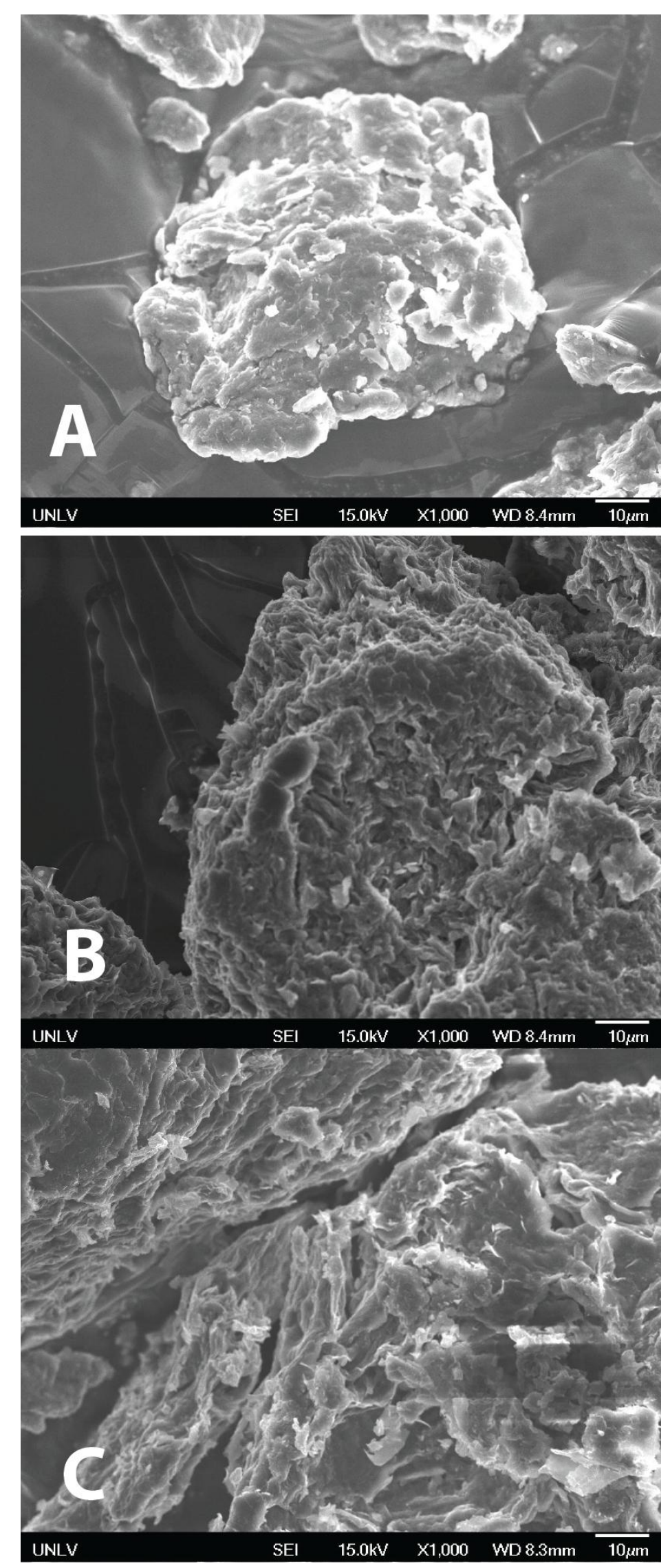
795 Figure 2. FE-SEM images of unreacted and reacted surfaces of NAu-1. (A) Unreacted

796 sieved and washed NAu-1 observed before dissolution experiments, compared to reacted

797 NAu-1 removed from dissolution experiments conducted at (B) $25.0^{\circ} \mathrm{C} a \mathrm{H}_{2} \mathrm{O}=1.00$

$798 \mathrm{CaCl}_{2}$, and (C) $25.0^{\circ} \mathrm{C} a \mathrm{H}_{2} \mathrm{O}=1.00 \mathrm{NaCl}$. Surface textures appear similar for all

799 experiments as well as the unreacted material. In each case, the scale bar is 10 micron.

800 

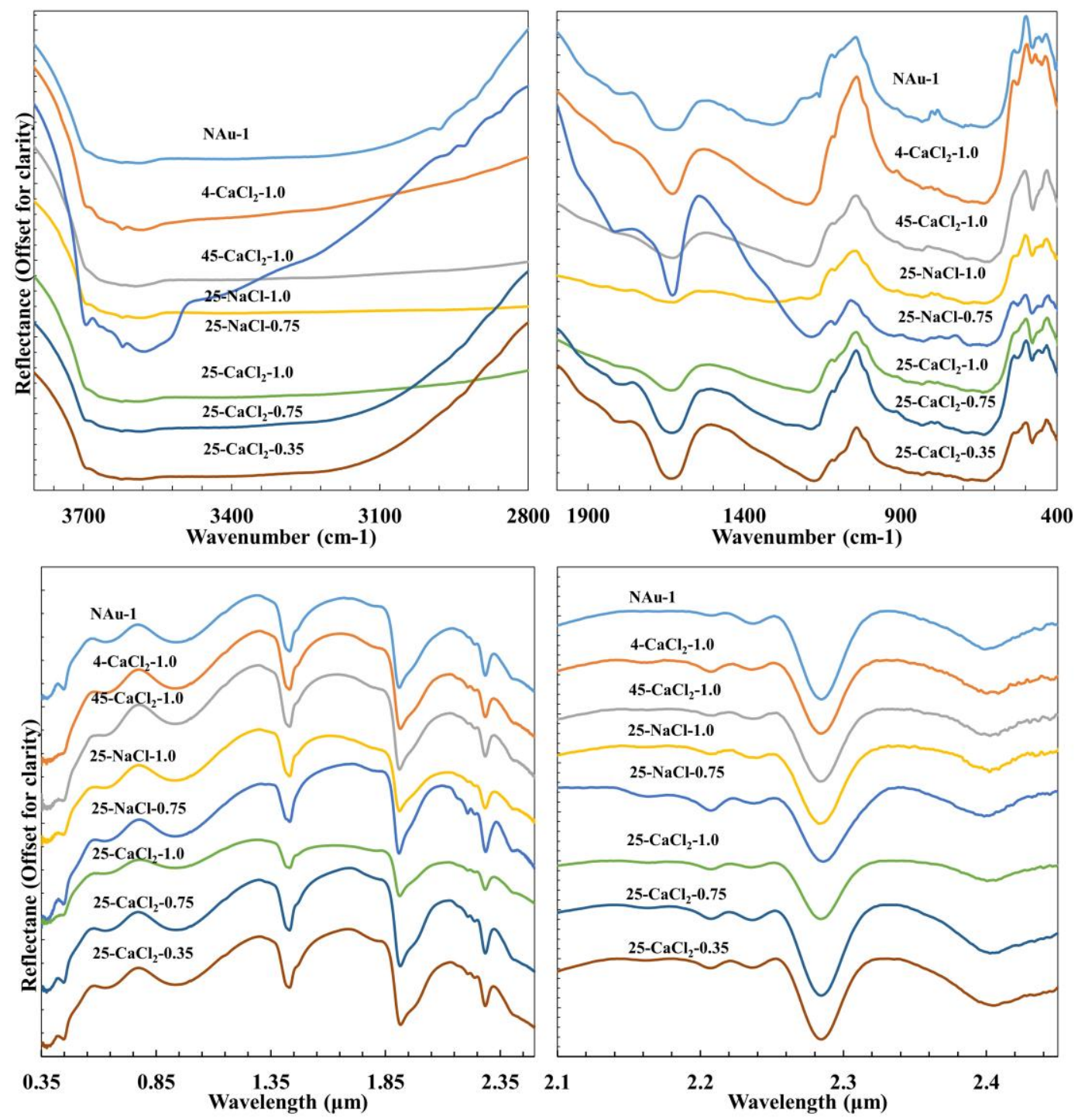

801

802 Figure 3. Top: FTIR spectra of unreacted and reacted nontronite, with the spectra from

803 wavenumber $2500-3900 \mathrm{~cm}^{-1}$ top left, and the spectra from wavenumber $1400-350$

$804 \mathrm{~cm}^{-1}$ top right. The Si-O stretch near $1000 \mathrm{~cm}^{-1}$ becomes narrower for all reacted samples.

805 A reflectance maximum/emission minimum at $1220 \mathrm{~cm}^{-1}$ and a feature at $790 \mathrm{~cm}^{-1}$

806 disappear in reacted samples compared to the unreacted NAu-1 spectra. The Al/Si-O-Si 
807 deformations between 600 and $400 \mathrm{~cm}^{-1}$ change in shape for all $25.0^{\circ} \mathrm{C}$ and $45.0^{\circ} \mathrm{C}$

808 experiments. The spectral properties of the $25-\mathrm{NaCl}-0.75$ sample near $3600 \mathrm{~cm}^{-1}$ may be

809 due to an initial trace phase or precipitated iron oxides and oxyhydroxides. In each case,

810 the sample analyzed was the first of the duplicates (Table 1), and the label indicates that

811 the sample was either the unreacted NAu-1, or the conditions of alteration, with the

812 temperature listed first, followed by the salt, followed by the activity of water in the

813 solution.

814

815 Bottom: VNIR spectra of unreacted and reacted nontronite at wavelengths from 0.5-2.5

$816 \mu \mathrm{m}$, offset for clarity, enlargement from $2.10 \mu \mathrm{m}$ to $2.45 \mu \mathrm{m}$ shown to the right. Little

817 change is noted with reaction - for samples treated with the $0.75 a \mathrm{H}_{2} \mathrm{O} \mathrm{CaCl}_{2}$ brine, there

818 is a slight change in the absorption near $2.43 \mu \mathrm{m}$ with a subtle shift of about $10 \mathrm{~nm}$

819 shortward. In each case the sample analyzed was the first of the duplicates (Table 1), and

820 the label indicates that the sample was either the unreacted NAu-1, or the conditions of

821 alteration, with the temperature listed first, followed by the salt, followed by the activity

822 of water in the solution.

823

824

825

826 

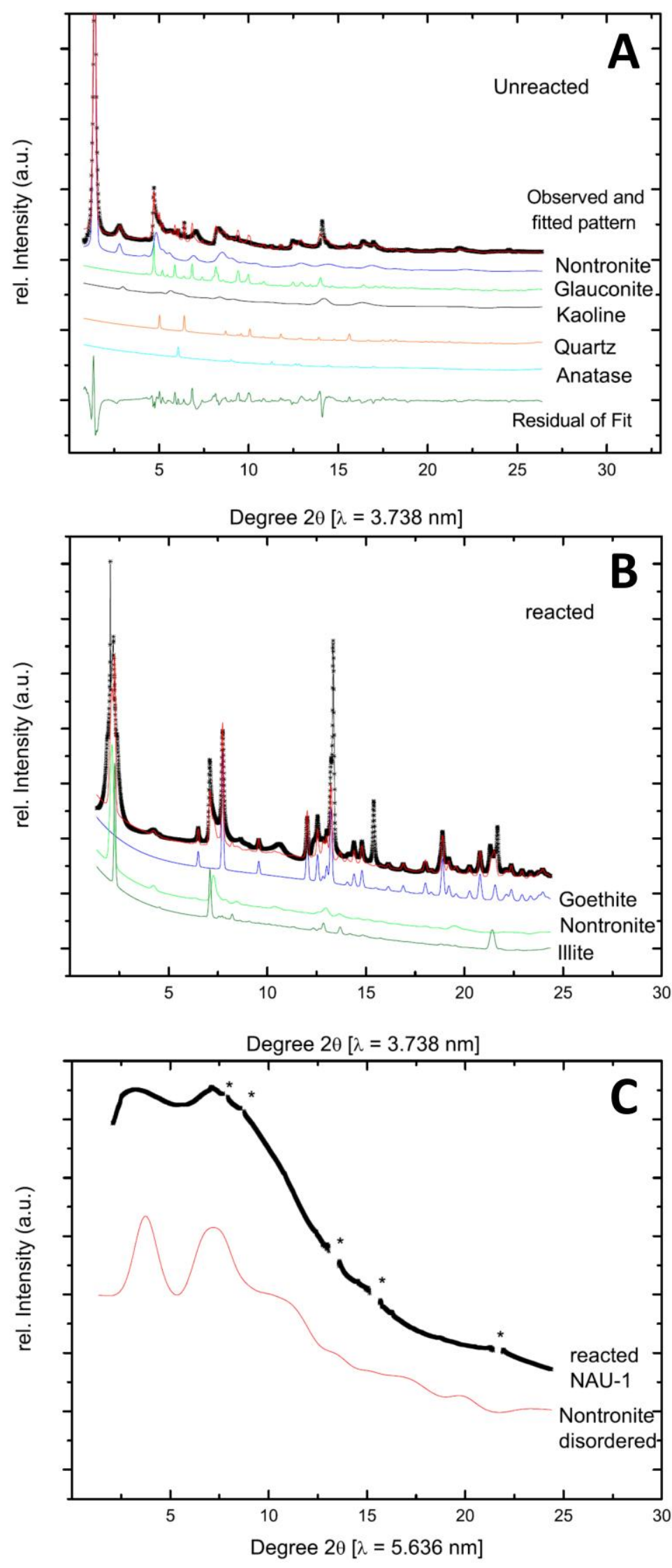
829 Figure 4. Synchrotron XRD analyses of a) unreacted NAu-1 b) a representative sample

830 of $\mathrm{NAu}-1$ reacted in $0.01 \mathrm{M} \mathrm{NaCl}$ solution, and c) a grain of whitish $\mathrm{NAu}-1$ that had been

831 reacted in a $0.01 \mathrm{M} \mathrm{NaCl}$ solution and was also common. Results indicate that unreacted

832 NAu-1 can be fit as bulk nontronite containing small amounts of kaolinite, quartz,

833 anatase and a $10 \AA$ phase in the glauconite-illite series. This is consistent with previous

834 analyses of NAu-1 that indicate that it contains traces of kaolinite, quartz and a $10 \AA$

835 phase (previously identified as biotite) along with 90\% nontronite (KEELING et al.

836 2000). Representative reacted NAu-1 can be fit as a mixture of bulk nontronite also

837 containing goethite, and the $10 \AA$ A phase in the glauconite-illite series. The $10 \AA ̊$ phase in

838 the glauconite-illite series and the biotite that has been previously detected in NAu-1

839 (KEELING et al., 2000) are likely to be the same or very similar, given their similarity by

840 X-ray diffraction. The representative reacted nontronite also shows a shift in the 001

841 peak to lower angles, possible due to cation exchange between the Ca originally in the

842 interlayer, and the $\mathrm{Na}$ in the solution, as well as an increase in peak width due to

843 weathering of nontronite, either due to a reduction in grainsize or intra-lattice (stacking)

844 disorder. This is relevant to smectites at Gale which also show a smaller basal spacing

845 (VANIMAN 2014), and may also enhance dissolution. MicroXRD analyses of whitish

846 grains of reacted NAu-1 indicate significant changes in grain size, and suggest the

847 formation of disordered nontronite (c). The presence of a material comparable with

848 disordered nontronite (c) is consistent with potential dissolution of nontronite and

849 reprecipitation of a disordered phase. The modeled pattern is that of bulk nontronite that

850 does not take into account the shape of the crystallites, and assumes that the bulk

851 structure of the nanocrystalline material is the same as that of the bulk nontronite. 


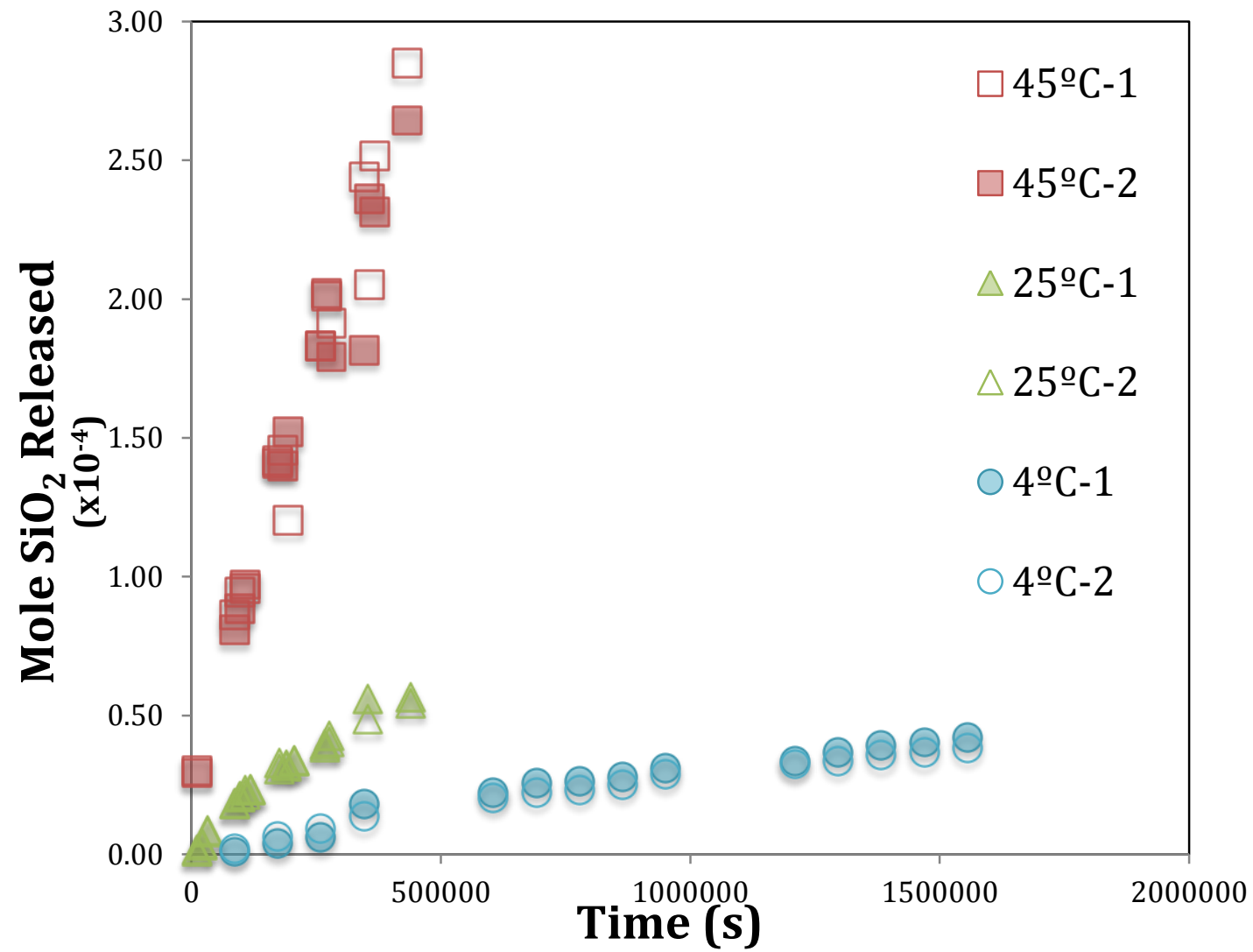

856 Figure 5. Moles silica released as a function of time at temperatures of $4.0^{\circ} \mathrm{C}, 25.0^{\circ} \mathrm{C}$,

857 and $45.0^{\circ} \mathrm{C}$ at $a \mathrm{H}_{2} \mathrm{O}=1.00$. Steeper slopes indicate faster dissolution, and these

858 experiments therefore indicate that dissolution increased with increasing temperature.

859 Analytical uncertainty on solution chemistry is smaller than all points. 


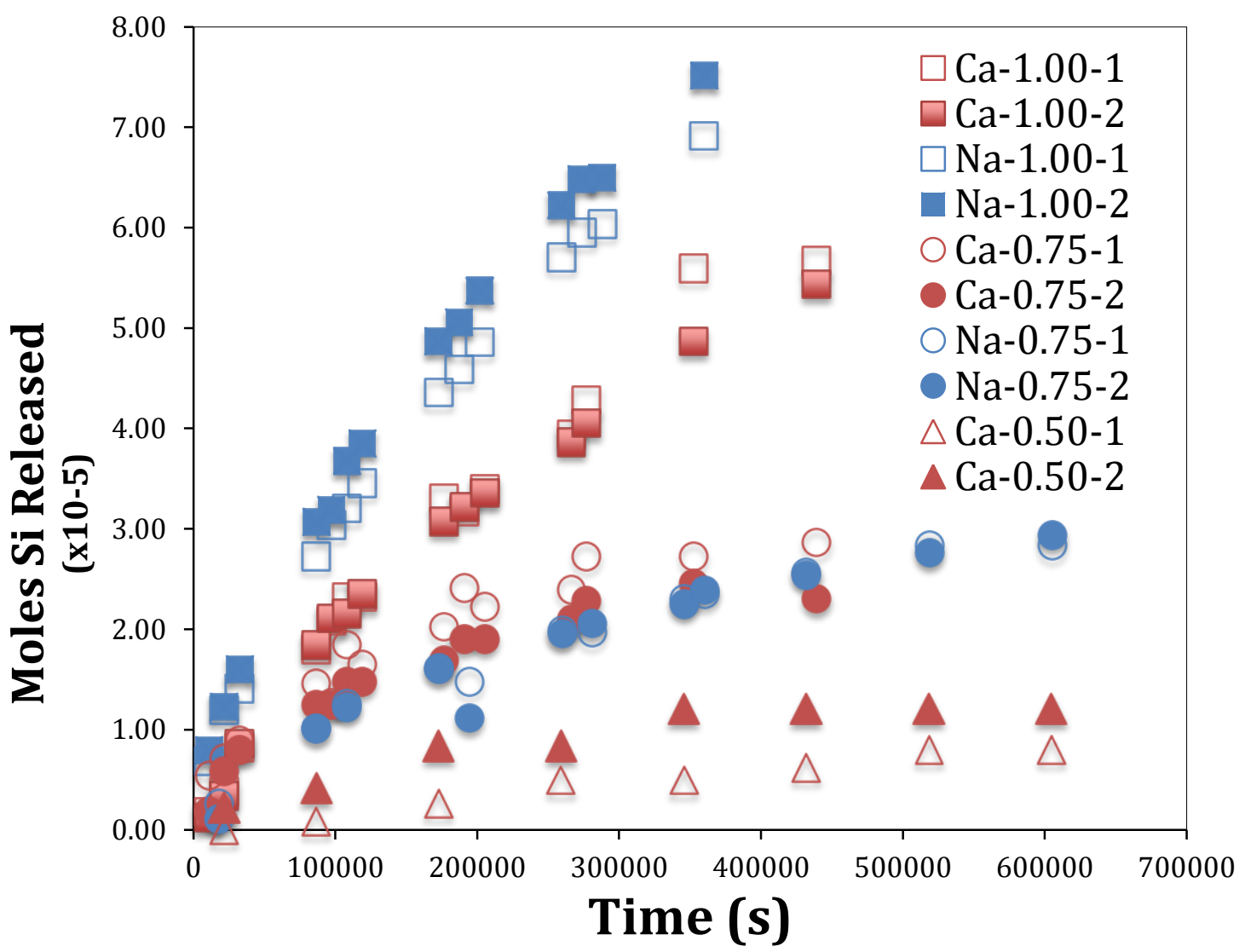

863 Figure 6. Moles silica released as a function of time at $a \mathrm{H}_{2} \mathrm{O}=1.00,0.75$, and 0.50 at 25

$864{ }^{\circ} \mathrm{C}$. Steeper slopes indicate faster dissolution. These experiments indicate dissolution

865 decreased with decreasing activity of water, and that in very dilute solutions, nontronite

866 dissolution is increased in the presence of $0.01 \mathrm{M} \mathrm{NaCl}$ solutions relative to $0.01 \mathrm{M}$

$867 \mathrm{CaCl}_{2}$ solutions. Samples were taken at different time intervals to accommodate different

868 dissolution rates. The $1.00 a \mathrm{H}_{2} \mathrm{O}$ and $0.75 a \mathrm{H}_{2} \mathrm{O}$ experiments were sampled 2-3 times a

869 day for one week while the $0.50 a \mathrm{H}_{2} \mathrm{O}$ experiments were sampled daily for three weeks.

870 Analytical uncertainty on solution chemistry is smaller than all points. 
872

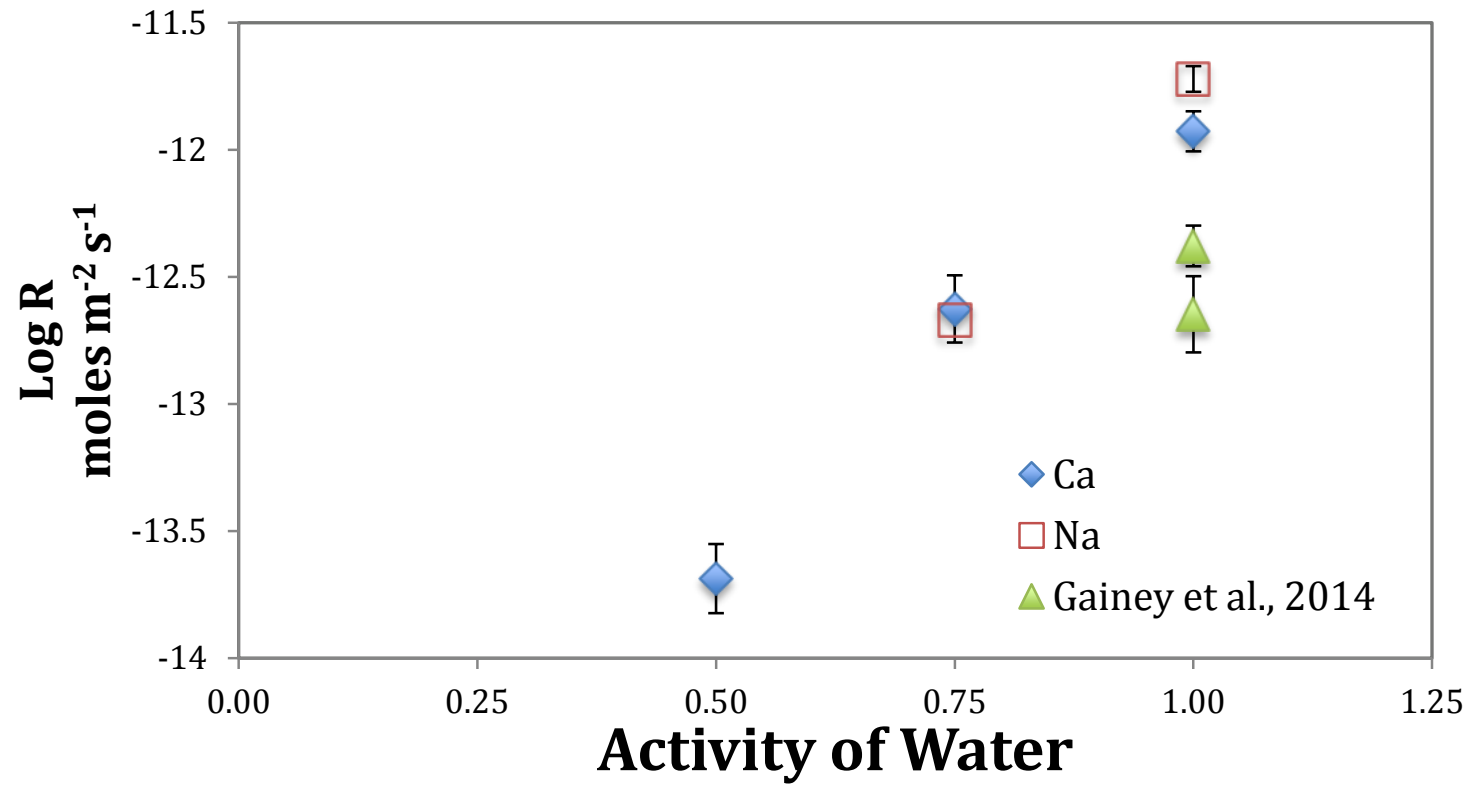

873

874 Figure 7. Log dissolution as a function of activity of water for dilute and brine

875 experiments at $25.0^{\circ} \mathrm{C}$ and $\mathrm{pH} 1.8-2.0$ show a decrease in dissolution with decreasing

876 activity of water. Rates from GAINEY et al. (2014) were measured at a flow rate $=0.1609$

$877 \mathrm{ml} / \mathrm{h}$ and $\mathrm{pH}=1.8 \mathrm{using}$ the same size fraction $\mathrm{NAu}-1$ as that used in this study. The rate

878 plotted here is the rate reported in GAINEY et al. (2014) normalized to the initial surface

879 area $\left(30.9 \pm 1.5 \mathrm{~m}^{2} \mathrm{~g}^{-1}\right)$ used in this study $\left(4.18 \times 10^{-13} \pm 2.8 \times 10^{-14}\right.$ moles mineral m $\left.\mathrm{m}^{-2} \mathrm{~s}^{-1}\right)$ to

880 better compare the results.

881

882 


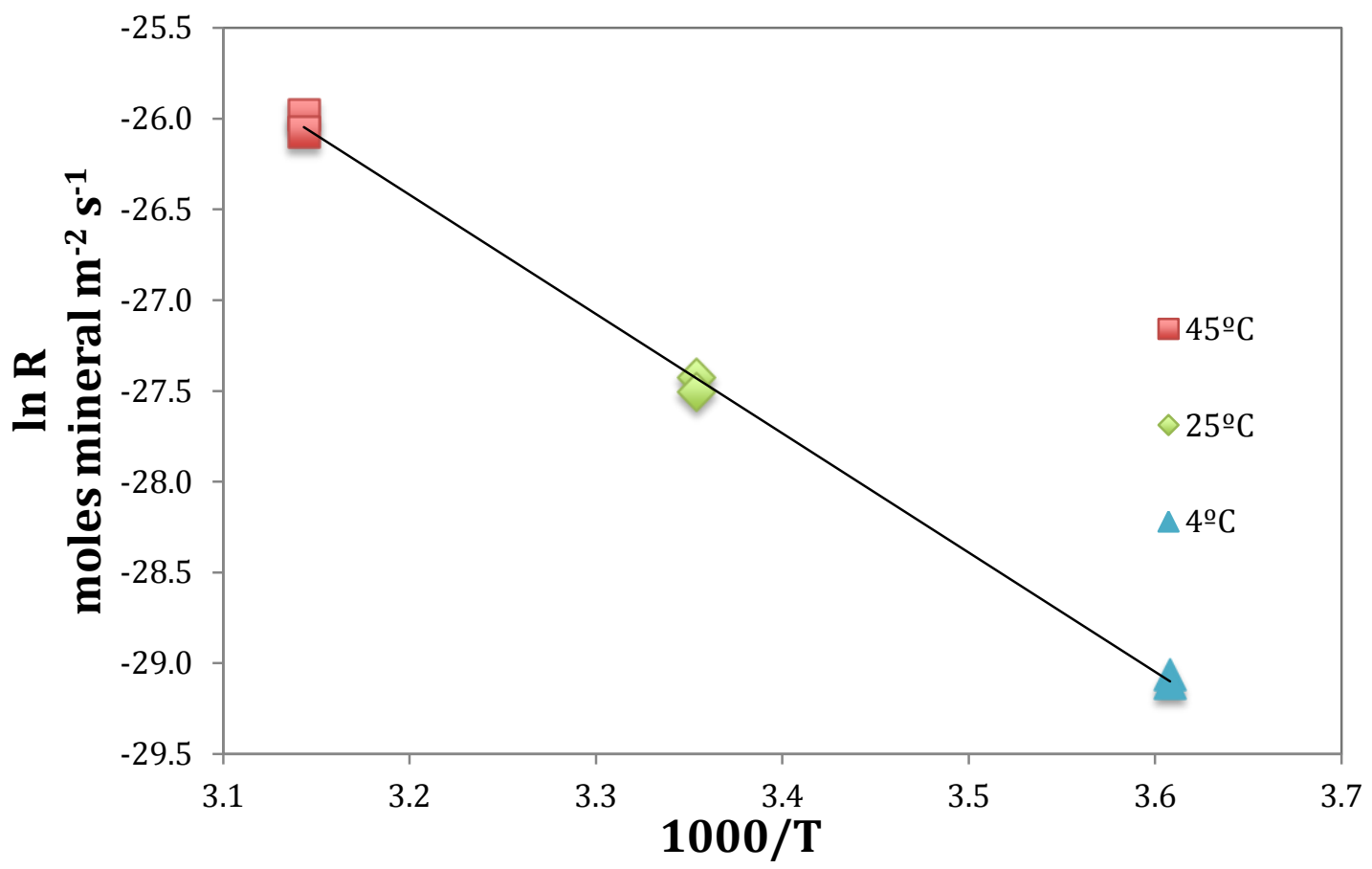

883

884 Figure 8. Arrhenius plot of nontronite dissolution at $\mathrm{pH}=2.0$ Measured uncertainties are

885 smaller than all points. The apparent activation energy is $54.6 \pm 1.0 \mathrm{~kJ} / \mathrm{mol}$

886

887 


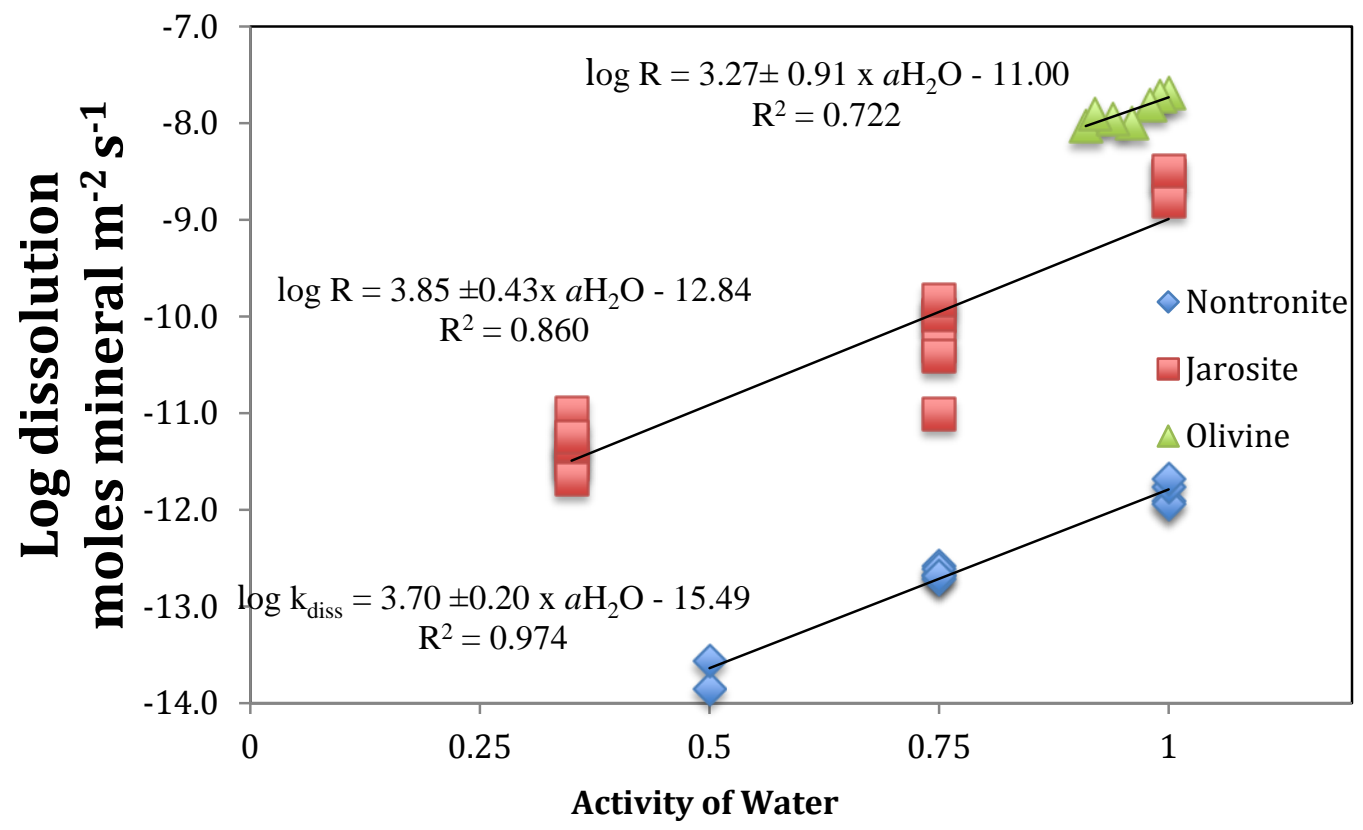

888

889

Figure 9. Comparison of dissolution of nontronite, jarosite and forsteritic olivine as a

890 function of activity of water. Activities cover a range of 1.0-0.5 for nontronite, 1.0-0.35

891 for K- and Na-jarosite, and 1.0-0.91 for forsteritic olivine. All experiments were

892 performed at temperatures from $23-26^{\circ} \mathrm{C}$; forsteritic olivine and nontronite dissolution

893 experiments were performed at $\mathrm{pH}=2.0$ For jarosite experiments with $a \mathrm{H}_{2} \mathrm{O}<1.00$ the

$894 \mathrm{pH}$ is $~ 3-4$.

895

896 


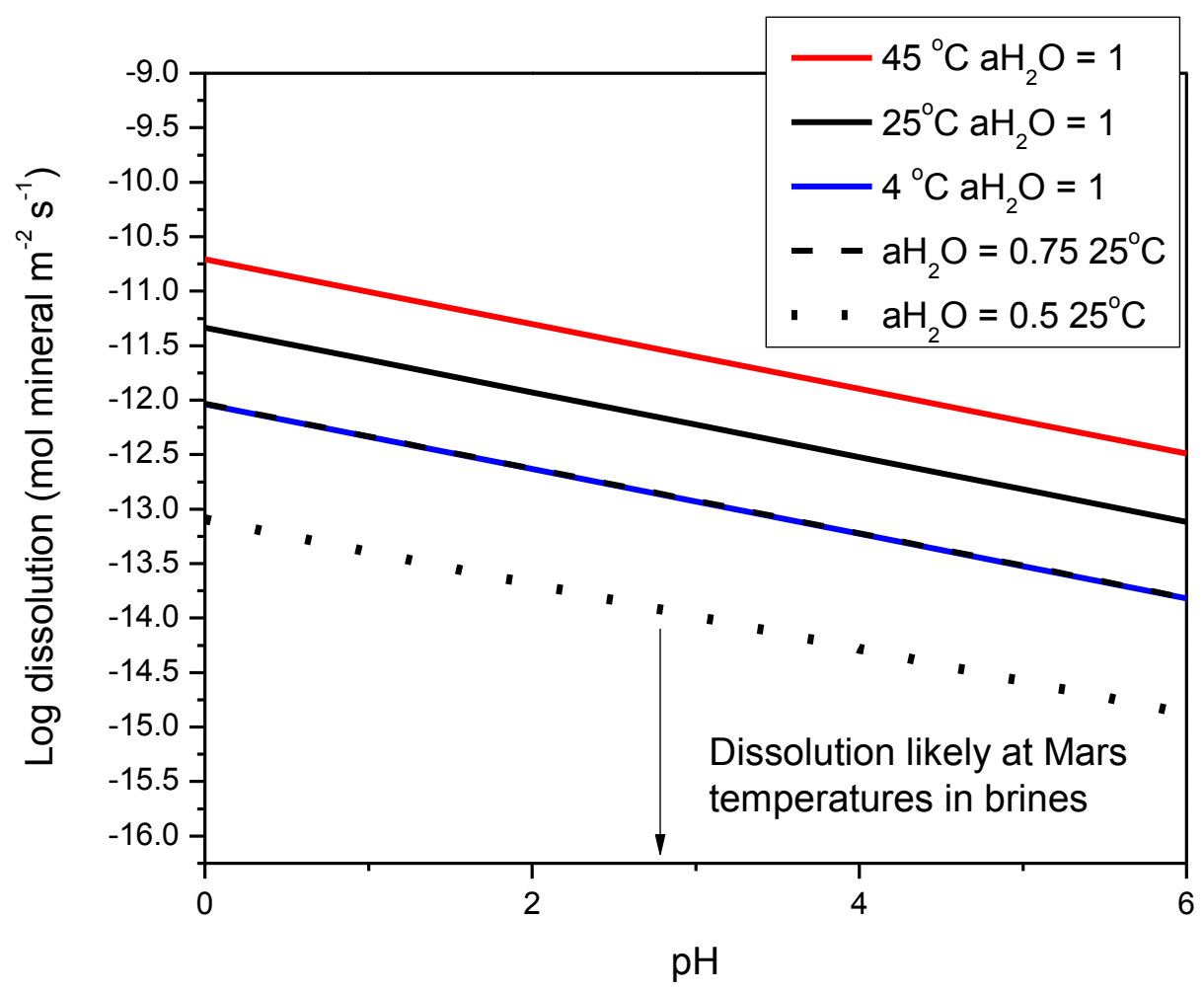

897

898 Figure 10. Nontronite dissolution as a function of $\mathrm{pH}$, temperature and activity of water

899 likely relevant to martian conditions. Lines show $\mathrm{k}_{\text {diss }}$ from this study at $\mathrm{pH}=2$ with a

900 linear $\mathrm{pH}$ dependence under acidic conditions from GAINEY et al. (2014), with the line

901 indicating the dissolution at $25.0^{\circ} \mathrm{C}$ at 0.75 activity of water overlying the line indicating

902 dissolution at $4.0{ }^{\circ} \mathrm{C}$ activity of water $=1.00$. Changes to nontronite dissolution caused by

903 changes in activity of water have a larger impact than temperature and $\mathrm{pH}$ under the

904 range of conditions examined here. Dissolution likely on Mars in brines at low

905 temperatures is indicated with the arrow. 

smectite dissolution rate under acidic conditions. Geochimica et Cosmochimica Acta 69, 2535-2546.

ASTM D859-10, Standard Test Method for Silica in Water. ASTM International, West Conshohocken, PA.

Bauer, A. and Berger, G., 1998. Kaolinite and smectite dissolution rate in high molar $\mathrm{KOH}$ solutions at $35^{\circ}$ and $80^{\circ} \mathrm{C}$. Applied Geochemistry 13, 905-916.

Bauer, K., Garbe, D., and Surburg, H., 1988. Ullmann's encyclopedia of industrial chemistry. Ullmann's Encyclopedia of Industrial Chemistry 11.

Bergaya, F. and Lagaly, G., 2013. Handbook of clay science. Newnes.

Bibring, J.-P., Langevin, Y., Mustard, J. F., Poulet, F., Arvidson, R., Gendrin, A., Gondet, B., Mangold, N., Pinet, P., and Forget, F., 2006. Global mineralogical and aqueous Mars history derived from OMEGA/Mars Express data. Science 312, 400-400-404.

Bishop, J. L., Dobrea, E. Z. N., McKeown, N. K., Parente, M., Ehlmann, B. L., Michalski, J. R., Milliken, R. E., Poulet, F., Swayze, G. A., and Mustard, J. F., 2008. Phyllosilicate diversity and past aqueous activity revealed at Mawrth Vallis, Mars. Science 321, 830-833.

Bowen, B. B. and Benison, K. C., 2009. Geochemical characteristics of naturally acid and alkaline saline lakes in southern Western Australia. Applied Geochemistry 24, 268-284.

Brass, G. W., 1980. Stability of brines on Mars. Icarus 42, 20-28.

Bridges, J. C., Catling, D. C., Saxton, J. M., Swindle, T. D., Lyon, I. C., and Grady, M. M., 2001. Alteration assemblages in Martian meteorites: Implications for nearsurface processes. Space Science Reviews 96, 365-392.

Brunauer, S., Emmett, P. H., and Teller, E., 1938. Adsorption of gases in multimolecular layers. Journal of the American Chemical Society 60, 309-319.

Cama, J. and Ganor, J., 2006. The effects of organic acids on the dissolution of silicate minerals: A case study of oxalate catalysis of kaolinite dissolution. Geochimica et Cosmochimica Acta 70, 2191-2209.

Cama, J., Metz, V., and Ganor, J., 2002. The effect of $\mathrm{pH}$ and temperature on kaolinite dissolution rate under acidic conditions. Geochimica et Cosmochimica Acta 66, 3913-3926.

Carroll-Webb, S. A. and Walther, J. V., 1988. A surface complex reaction model for the $\mathrm{pH}$-dependence of corundum and kaolinite dissolution rates. Geochimica et Cosmochimica Acta 52, 2609-2623.

Carroll, S. A. and Walther, J. V., 1990 . Kaolinite dissolution at $25^{\circ}, 60^{\circ}$, and $80^{\circ} \mathrm{C}$. American Journal of Science 290, 797-810.

Chevrier, V. F. and Rivera-Valentin, E. G., 2012. Formation of recurring slope lineae by liquid brines on present-day Mars. Geophysical Research Letters 39, n/an/a.

Chin, P.-K. F. and Mills, G. L., 1991. Kinetics and mechanisms of kaolinite dissolution: effects of organic ligands. Chemical Geology 90, 307-317. 
954 Chirife, J. and Resnik, S. L., 1984. Unsaturated solutions of sodium chloride as

955

956

957

958

959

960

961

962

963

964

965

966

967

968

969

970

971

972

973

974

975

976

977

978

979

980

981

982

983

984

985

986

987

988

989

990

991

992

993

994

995

996

997

998 reference sources of water activity at various temperatures. Journal of Food Science 49, 1486-1488.

Corporation, P.-E., 1964. Analytical methods for atomic absorption spectrophotometry.

Cull, S. C., Arvidson, R. E., Catalano, J. G., Ming, D. W., Morris, R. V., Mellon, M. T., and Lemmon, M., 2010. Concentrated perchlorate at the Mars Phoenix landing site: Evidence for thin film liquid water on Mars. Geophysical Research Letters 37.

Devidal, J.-L., Dandurand, J. L., and Schott, J., 1992. Dissolution and precipitation kinetics of kaolinite as a function of chemical affinity $\left(\mathrm{T}=150^{\circ} \mathrm{C}, \mathrm{pH}=2\right.$ and 7.8). In: Kharaka, Y. and Maest, A. Eds.)Water-Rock Interaction 7. Balkema, Park City, UT, USA.

Dixon, E., Elwood Madden, A., Hausrath, E. M., and Elwood Madden, M. E., 2015. Assesing Hydrodynamic effects on jarosite dissolution rates, reaction products, and preservation on Mars. Journal of Geophysical Research Planets.

Dixon, J. C., Thorn, C. E., Darmody, R. G., and Campbell, S. W., 2002. Weathering rinds and rock coatings from an Arctic alpine environment, northern Scandinavia. Geological Society of America Bulletin 114, 226-238.

Dorn, R. I., 1998. Rock coatings. Elsevier.

Dove, P. M. and Nix, C. J., 1997. The influence of the alkaline earth cations, magnesium, calcium, and barium on the dissolution kinetics of quartz. Geochimica et Cosmochimica Acta 61, 3329-3340.

Eaton, A. D., Clesceri, L. S., Rice, E. W., Greenberg, A. E., and Franson, M. A. H., 2005. Standard Methods for the Examination of Water and Wastewater: Centennial Edition. American Public Health Association., Washington, D.C.

Ehlmann, B. L., Mustard, J. F., Swayze, G. A., Clark, R. N., Bishop, J. L., Poulet, F., Des Marais, D. J., Roach, L. H., Milliken, R. E., Wray, J. J., Barnouin-Jha, O., and Murchie, S. L., 2009. Identification of hydrated silicate minerals on Mars using MRO-CRISM: Geologic context near Nili Fossae and implications for aqueous alteration. Journal of Geophysical Research: Planets 114, E00D08.

Fairen, A. G., Davila, A. F., Gago-Duport, L., Amils, R., and McKay, C. P., 2009. Stability against freezing of aqueous solutions on early Mars. Nature 459, 401-4.

Fishman, M. and Friedman, L. C., 1989. Techniques of water-resources investigations of the United States Geological Survey. Chapter A1: Methods for Determination of Inorganic Substances in Water and Fluvial Sediments, TWRI, 5-A1.

Furrer, G., Zysset, M., and Schindler, P., 1993. Weathering kinetics of montmorillonite: Investigations in batch and mixed-flow reactors. Geochemistry of clay-pore fluid interaction 4, 243-262.

Gainey, S. R., Hausrath, E. M., Hurowitz, J. A., and Milliken, R. E., 2014. Nontronite dissolution rates and implications for Mars. Geochimica et Cosmochimica Acta 126, 192-211.

Ganor, J., Mogollon, J. L., and Lasaga, A. C., 1995. The effect of pH on kaolinite dissolution rates and on activation energy. Geochimica et Cosmochimica Acta 59, 1037-1052. 
Gates, W. P., Slade, P. G., Manceau, A., and Lanson, B., 2002. SITE OCCUPANCIES BY IRON IN NONTRONITES. Clays and Clay Minerals 50, 223-239.

Goetz, W., Bertelsen, P., Binau, C. S., Gunnlaugsson, H. P., Hviid, S. F., Kinch, K. M., Madsen, D. E., Madsen, M. B., Olsen, M., Gellert, R., Klingelhofer, G., Ming, D. W., Morris, R. V., Rieder, R., Rodionov, D. S., de Souza, P. A., Schroder, C., Squyres, S. W., Wdowiak, T., and Yen, A., 2005. Indication of drier periods on Mars from the chemistry and mineralogy of atmospheric dust. Nature 436, 62-65.

Govett, G., 1961. Critical factors in the colorimetric determination of silica. Analytica Chimica Acta 25, 69-80.

Grant, W. D., 2004. Life at low water activity. Philosophical transactions of the Royal Society of London. Series B, Biological sciences 359, 1249-66; discussion 12667.

Haberle, R. M., McKay, C. P., Schaeffer, J., Cabrol, N. A., Grin, E. A., Zent, A. P., and Quinn, R., 2001. On the possibility of liquid water on present-day Mars. Journal of Geophysical Research E: Planets 106, 23317-23326.

Harter, R. D. and Naidu, R., 2001. An assessment of environmental and solution parameter impact on trace-metal sorption by soils. Soil Science Society of America Journal 65, 597-612.

Haskin, L. A., Wang, A., Jolliff, B. L., McSween, H. Y., Clark, B. C., Des Marais, D. J., McLennan, S. M., Tosca, N. J., Hurowitz, J. A., and Farmer, J. D., 2005. Water alteration of rocks and soils on Mars at the Spirit rover site in Gusev crater. Nature 436, 66-69.

Hausrath, E., Treiman, A., Vicenzi, E., Bish, D., Blake, D., Sarrazin, P., Hoehler, T., Midtkandal, I., Steele, A., and Brantley, S., 2008. Short-and long-term olivine weathering in Svalbard: implications for Mars. Astrobiology 8, 1079-1092.

Hausrath, E. M. and Brantley, S. L., 2010. Basalt and olivine dissolution under cold, salty, and acidic conditions: What can we learn about recent aqueous weathering on Mars? Journal of Geophysical Research 115.

Hecht, M. H., 2002. Metastability of Liquid Water on Mars. Icarus 156, 373-386.

Henderson-Sellers, A. and Meadows, A. J., 1976. The evolution of the surface temperature of Mars. Planetary and Space Science 24, 41-44.

Huertas, F. J., Caballero, E., Jiménez de Cisneros, C., Huertas, F., and Linares, J., 2001. Kinetics of montmorillonite dissolution in granitic solutions. Applied Geochemistry 16, 397-407.

Huertas, F. J., Chou, L., and Wollast, R., 1998. Mechanism of Kaolinite Dissolution at Room Temperature and Pressure: Part 1. Surface Speciation. Geochimica et Cosmochimica Acta 62, 417-431.

Huertas, F. J., Chou, L., and Wollast, R., 1999a. Mechanism of kaolinite dissolution at room temperature and pressure Part II: kinetic study. Geochimica et Cosmochimica Acta 63, 3261-3275.

Huertas, F. J., Fiore, S., Huertas, F., and Linares, J., 1999b. Experimental study of the hydrothermal formation of kaolinite. Chemical Geology 156, 171-190.

Icopini, G. A., Brantley, S. L., and Heaney, P. J., 2005. Kinetics of silica oligomerization and nanocolloid formation as a function of $\mathrm{pH}$ and ionic strength at $25 \mathrm{C}$. Geochimica et Cosmochimica Acta 69, 293-303. 
Iler, R. K., 1979. The chemistry of silica.

Ingersoll, A. P., 1970. Mars: Occurrence of Liquid Water. Science 168, 972-973. the water"? Astrobiology 10, 349-361.

Keeling, J. L., Raven, M. D., and Gates, W. P., 2000. Geology and characterization of two hydrothermal nontronites from weathered metamorphic rocks at the Uley Graphite Mine, South Australia. Clays and Clay Minerals 48, 537-548.

Knauth, L. P. and Burt, D. M., 2002. Eutectic Brines on Mars: Origin and Possible Relation to Young Seepage Features. Icarus 158, 267-271.

Komadel, P., 2003. Chemically modified smectitesClay Minerals.

Kraft, M. D., Michalski, J. R., and Sharp, T. G., 2003. Effects of pure silica coatings on thermal emission spectra of basaltic rocks: Considerations for Martian surface mineralogy. Geophysical Research Letters 30.

Kreslavsky, M. A. and Head, J. W., 2009. Slope streaks on Mars: A new "wet" mechanism. Icarus 201, 517-527.

Kunz, M., MacDowell, A. A., Caldwell, W. A., Cambie, D., Celestre, R. S., Domning, E. E., Duarte, R. M., Gleason, A. E., Glossinger, J. M., Kelez, N., Plate, D. W., Yu, T., Zaug, J. M., Padmore, H. A., Jeanloz, R., Alivisatos, A. P., and Clark, S. M., 2005. A beamline for high-pressure studies at the Advanced Light Source with a superconducting bending magnet as the source. Journal of Synchrotron Radiation 12, 650-658.

Loizeau, D., Mangold, N., Poulet, F., Ansan, V., Hauber, E., Bibring, J.-P., Gondet, B., Langevin, Y., Masson, P., and Neukum, G., 2010. Stratigraphy in the Mawrth Vallis region through OMEGA, HRSC color imagery and DTM. Icarus 205, 396418.

Martín-Torres, F. J., Zorzano, M.-P., Valentín-Serrano, P., Harri, A.-M., Genzer, M., Kemppinen, O., Rivera-Valentin, E. G., Jun, I., Wray, J., Bo Madsen, M., Goetz, W., McEwen, A. S., Hardgrove, C., Renno, N., Chevrier, V. F., Mischna, M., Navarro-González, R., Martínez-Frías, J., Conrad, P., McConnochie, T., Cockell, C., Berger, G., R. Vasavada, A., Sumner, D., and Vaniman, D., 2015. Transient liquid water and water activity at Gale crater on Mars. Nature Geoscience.

Martínez, G. M. and Renno, N. O., 2013. Water and Brines on Mars: Current Evidence and Implications for MSL. Space Science Reviews 175, 29-51.

Marty, N. C. M., Cama, J., Sato, T., Chino, D., Villiéras, F., Razafitianamaharavo, A., Brendlé, J., Giffaut, E., Soler, J. M., Gaucher, E. C., and Tournassat, C., 2011. Dissolution kinetics of synthetic Na-smectite. An integrated experimental approach. Geochimica et Cosmochimica Acta 75, 5849-5864.

McEwen, A. S., Ojha, L., Dundas, C. M., Mattson, S. S., Byrne, S., Wray, J. J., Cull, S. C., Murchie, S. L., Thomas, N., and Gulick, V. C., 2011. Seasonal flows on warm Martian slopes. Science 333, 740-743.

McKeown, N. K., Bishop, J. L., Noe Dobrea, E. Z., Ehlmann, B. L., Parente, M., Mustard, J. F., Murchie, S. L., Swayze, G. A., Bibring, J. P., and Silver, E. A., 2009. Characterization of phyllosilicates observed in the central Mawrth Vallis region, Mars, their potential formational processes, and implications for past climate. Journal of Geophysical Research: Planets (1991-2012) 114. 
1090

1091

1092

1093

1094

1095

1096

1097

1098

1099

1100

1101

1102

1103

1104

1105

1106

1107

1108

1109

1110

1111

1112

1113

1114

1115

1116

1117

1118

1119

1120

1121

1122

1123

1124

1125

1126

1127

1128

1129

1130

1131

1132

1133

1134

1135
Metz, V., Amram, K., and Ganor, J., 2005. Stoichiometry of smectite dissolution reaction. Geochimica et Cosmochimica Acta 69, 1755-1772.

Metz, V. and Ganor, J., 2001. Stirring effect on kaolinite dissolution rate. Geochimica et Cosmochimica Acta 65, 3475-3490.

Michalski, J. R., Kraft, M. D., Diedrich, T., Sharp, T. G., and Christensen, P. R., 2003. Thermal emission spectroscopy of the silica polymorphs and considerations for remote sensing of Mars. Geophysical research letters $\mathbf{3 0 .}$

Michalski, J. R., Kraft, M. D., Sharp, T. G., Williams, L. B., and Christensen, P. R., 2005. Mineralogical constraints on the high-silica martian surface component observed by TES. Icarus 174, 161-177.

Miller, M. A., Madden, A. S., Madden, M. E., and Elmore, R. D., 2012. LABORATORYSIMULATED DIAGENESIS OF NONTRONITE. Clays and Clay Minerals 60, 616632.

Milliken, R., Grotzinger, J., and Thomson, B., 2010. Paleoclimate of Mars as captured by the stratigraphic record in Gale Crater. Geophysical Research Letters 37.

Ming, D. W., Gellert, R., Morris, R. V., Arvidson, R. E., Brückner, J., Clark, B. C., Cohen, B. A., D'Uston, C., Economou, T., Fleischer, I., Klingelhöfer, G., McCoy, T. J., Mittlefehldt, D. W., Schmidt, M. E., Schröder, C., Squyres, S. W., Tréguier, E., Yen, A. S., and Zipfel, J., 2008. Geochemical properties of rocks and soils in Gusev Crater, Mars: Results of the Alpha Particle X-Ray Spectrometer from Cumberland Ridge to Home Plate. Journal of Geophysical Research E: Planets 113.

Murchie, S. L., Mustard, J. F., Ehlmann, B. L., Milliken, R. E., Bishop, J. L., McKeown, N. K., Noe Dobrea, E. Z., Seelos, F. P., Buczkowski, D. L., Wiseman, S. M., Arvidson, R. E., Wray, J. J., Swayze, G., Clark, R. N., Des Marais, D. J., McEwen, A. S., and Bibring, J. P., 2009. A synthesis of Martian aqueous mineralogy after 1 Mars year of observations from the Mars Reconnaissance Orbiter. Journal of Geophysical Research E: Planets 114.

Mustard, J. F., Murchie, S. L., Pelkey, S. M., Ehlmann, B. L., Milliken, R. E., Grant, J. A., Bibring, J. P., Poulet, F., Bishop, J., Dobrea, E. N., Roach, L., Seelos, F., Arvidson, R. E., Wiseman, S., Green, R., Hash, C., Humm, D., Malaret, E., McGovern, J. A., Seelos, K., Clancy, T., Clark, R., Des Marais, D., Izenberg, N., Knudson, A., Langevin, Y., Martin, T., McGuire, P., Morris, R., Robinson, M., Roush, T., Smith, M., Swayze, G., Taylor, H., Titus, T., and Wolff, M., 2008. Hydrated silicate minerals on Mars observed by the Mars Reconnaissance Orbiter CRISM instrument. Nature 454, 305-309.

Myllykylä, E., Tanhua-Tyrkkö, M., Bouchet, A., and Tiljander, M., 2013. Dissolution experiments of $\mathrm{Na}$ - and $\mathrm{Ca}$-montmorillonite in groundwater simulants under anaerobic conditions. Clay Minerals 48, 295-308.

Nagy, K., 1995. Dissolution and precipitation kinetics of sheet silicates. Reviews in Mineralogy and Geochemistry 31, 173-233.

Nagy, K. L., Blum, A. E., and Lasaga, A. C., 1991. Dissolution and precipitation kinetics of kaolinite at $80^{\circ} \mathrm{C}$ and $\mathrm{pH}$ 3: the dependence on solution saturation state. American Journal of Science 291, 649-686.

Navrotsky, A., Mazeina, L., and Majzlan, J., 2008. Size-Driven Structural and Thermodynamic Complexity in Iron Oxides. Science 319, 1635-1638. 
1136

1137

1138

1139

1140

1141

1142

1143

1144

1145

1146

1147

1148

1149

1150

1151

1152

1153

1154

1155

1156

1157

1158

1159

1160

1161

1162

1163

1164

1165

1166

1167

1168

1169

1170

1171

1172

1173

1174

1175

1176

1177

1178

1179

1180

Noe Dobrea, E., Bishop, J., McKeown, N., Fu, R., Rossi, C., Michalski, J., Heinlein, C., Hanus, V., Poulet, F., and Mustard, R., 2010. Mineralogy and stratigraphy of phyllosilicate - bearing and dark mantling units in the greater Mawrth Vallis/west Arabia Terra area: Constraints on geological origin. Journal of Geophysical Research: Planets (1991-2012) 115.

Ojha, L., Wilhelm, M. B., Murchie, S. L., McEwen, A. S., Wray, J. J., Hanley, J., Masse, M., and Chojnacki, M., 2015. Spectral evidence for hydrated salts in recurring slope lineae on Mars. Nature Geosci 8, 829-832.

Olsen, A. A., Hausrath, E. M., and Rimstidt, J. D., 2015. Forsterite dissolution rates in Mg-sulfate-rich Mars-analog brines, and implications the aqueous history of Mars.

Osterloo, M. M., Anderson, F. S., Hamilton, V. E., and Hynek, B. M., 2010. Geologic context of proposed chloride-bearing materials on Mars. Journal of Geophysical Research E: Planets 115.

Osterloo, M. M., Hamilton, V. E., Bandfield, J. L., Glotch, T. D., Baldridge, A. M., Christensen, P. R., Tornabene, L. L., and Anderson, F. S., 2008. ChlorideBearing Materials in the Southern Highlands of Mars. Science 319, 16511654.

Palandri, J. L. and Kharaka, Y. K., 2004. A compilation of rate parameters of watermineral interaction kinetics for application to geochemical modeling. DTIC Document.

Parkhurst, D. L. and Appelo, C., 1999. User's guide to PHREEQC (Version 2): A computer program for speciation, batch-reaction, one-dimensional transport, and inverse geochemical calculations.

Poulet, F., Bibring, J. P., Mustard, J. F., Gendrin, A., Mangold, N., Langevin, Y., Arvidson, R. E., Gondet, B., Gomez, C., Berthe, M., Erard, S., Forni, O., Manaud, N., Poulleau, G., Soufflot, A., Combes, M., Drossart, P., Encrenaz, T., Fouchet, T., Melchiorri, R., Bellucci, G., Altieri, F., Formisano, V., Fonti, S., Capaccioni, F., Cerroni, P., Coradini, A., Korablev, O., Kottsov, V., Ignatiev, N., Titov, D., Zasova, L., Pinet, P., Schmitt, B., Sotin, C., Hauber, E., Hoffmann, H., Jaumann, R., Keller, U., Forget, F., and Omega, T., 2005. Phyllosilicates on Mars and implications for early martian climate. Nature 438, 623-7.

Pritchett, B. N., Elwood Madden, M. E., and Madden, A. S., 2012. Jarosite dissolution rates and maximum lifetimes in high salinity brines: Implications for Earth and Mars. Earth and Planetary Science Letters 357-358, 327-336.

Rao, M. N., Sutton, S. R., McKay, D. S., and Dreibus, G., 2005. Clues to Martian brines based on halogens in salts from nakhlites and MER samples. Journal of Geophysical Research E: Planets 110, 1-12.

Rard, J. A. and Clegg, S. L., 1997. Critical Evaluation of the Thermodynamic Properties of Aqueous Calcium Chloride. 1. Osmotic and Activity Coefficients of 0-10.77 mol $\odot \mathrm{kg}-1$ Aqueous Calcium Chloride Solutions at $298.15 \mathrm{~K}$ and Correlation with Extended Pitzer Ion-Interaction Models. Journal of Chemical \& Engineering Data 42, 819-849.

Rennó, N. O., Bos, B. J., Catling, D., Clark, B. C., Drube, L., Fisher, D., Goetz, W., Hviid, S. F., Keller, H. U., Kok, J. F., Kounaves, S. P., Leer, K., Lemmon, M., Madsen, M. B., 
1181

1182

1183

1184

1185

1186

1187

1188

1189

1190

1191

1192

1193

1194

1195

1196

1197

1198

1199

1200

1201

1202

1203

1204

1205

1206

1207

1208

1209

1210

1211

1212

1213

1214

1215

1216

1217

1218

1219

1220

1221

1222

1223

1224

1225

1226

Markiewicz, W. J., Marshall, J., McKay, C., Mehta, M., Smith, M., Zorzano, M. P., Smith, P. H., Stoker, C., and Young, S. M. M., 2009. Possible physical and thermodynamical evidence for liquid water at the Phoenix landing site. Journal of Geophysical Research 114.

Roach, L. H., Mustard, J. F., Swayze, G., Milliken, R. E., Bishop, J. L., Murchie, S. L., and Lichtenberg, K., 2010. Hydrated mineral stratigraphy of Ius Chasma, Valles Marineris. Icarus 206, 253-268.

Rozalén, M. L., Huertas, F. J., Brady, P. V., Cama, J., García-Palma, S., and Linares, J., 2008. Experimental study of the effect of pH on the kinetics of montmorillonite dissolution at $25^{\circ} \mathrm{C}$. Geochimica et Cosmochimica Acta 72, 4224-4253.

Smith, P. H., Tamppari, L. K., Arvidson, R. E., Bass, D., Blaney, D., Boynton, W. V., Carswell, A., Catling, D. C., Clark, B. C., Duck, T., DeJong, E., Fisher, D., Goetz, W., Gunnlaugsson, H. P., Hecht, M. H., Hipkin, V., Hoffman, J., Hviid, S. F., Keller, H. U., Kounaves, S. P., Lange, C. F., Lemmon, M. T., Madsen, M. B., Markiewicz, W. J., Marshall, J., McKay, C. P., Mellon, M. T., Ming, D. W., Morris, R. V., Pike, W. T., Renno, N., Staufer, U., Stoker, C., Taylor, P., Whiteway, J. A., and Zent, A. P., 2009. H20 at the phoenix landing site. Science 325, 58-61.

Soong, C., 1993. Hydrothermal kinetics of kaolinite-water interaction at pH 4.2 and 7.3, 130 C to 230 C, Pennsylvania State University.

Sverdrup, H. U., 1990. The kinetics of base cation release due to chemical weathering.

Tanakaa, M. and Takahashib, K., 2001. Silicate species in high pH solution molybdate, whose silica concentration is determined by colorimetry. Analytica Chimica Acta 429, 117-123.

Tardy, Y. and Fritz, B., 1981. An ideal solid solution model for calculating solubility of clay minerals. Clay Minerals 16, 361-373.

Tardy, Y. and Garrels, K. M., 1974. A method of estimating the Gibbs energies of formation of layer silicates. Geochimica et Cosmochimica Acta 38, 1101-1116.

Thomson, B. J., Bridges, N. T., Milliken, R., Baldridge, A., Hook, S. J., Crowley, J. K., Marion, G. M., de Souza Filho, C. R., Brown, A. J., and Weitz, C. M., 2011. Constraints on the origin and evolution of the layered mound in Gale Crater, Mars using Mars Reconnaissance Orbiter data. Icarus 214, 413-432.

Tosca, N. J. and McLennan, S. M., 2006. Chemical divides and evaporite assemblages on Mars. Earth and Planetary Science Letters 241, 21-31.

Velde, B., 1995. Composition and mineralogy of clay minerals, Origin and mineralogy of clays. Springer.

Wang, A., Haskin, L. A., Squyres, S. W., Jolliff, B. L., Crumpler, L., Gellert, R., Schröder, C., Herkenhoff, K., Hurowitz, J., Tosca, N. J., Farrand, W. H., Anderson, R., and Knudson, A. T., 2006. Sulfate deposition in subsurface regolith in Gusev crater, Mars. Journal of Geophysical Research E: Planets 111.

Welch, S. A. and Ullman, W. J., 2000. The temperature dependence of bytownite feldspar dissolution in neutral aqueous solutions of inorganic and organic ligands at low temperature (5-35 C). Chemical Geology 167, 337-354.

Wieland, E. and Stumm, W., 1992. Dissolution kinetics of kaolinite in acidic aqueous solutions at $25^{\circ} \mathrm{C}$. Geochimica et Cosmochimica Acta 56, 3339-3355. 
1227 Wordsworth, R. D., 2016. The Climate of Early Mars. Annual Review of Earth and $1228 \quad$ Planetary Sciences 44, 381-408.

1229 Wray, J., Ehlmann, B., Squyres, S., Mustard, J., and Kirk, R., 2008. Compositional 1230 stratigraphy of clay - bearing layered deposits at Mawrth Vallis, Mars.

$1231 \quad$ Geophysical Research Letters 35.

1232 Wray, J. J., Milliken, R. E., Dundas, C. M., Swayze, G. A., Andrews-Hanna, J. C.,

1233

1234

1235

1236

1237

1238 Baldridge, A. M., Chojnacki, M., Bishop, J. L., Ehlmann, B. L., Murchie, S. L., Clark, R. N., Seelos, F. P., Tornabene, L. L., and Squyres, S. W., 2011. Columbus crater and other possible groundwater-fed paleolakes of Terra Sirenum, Mars. Journal of Geophysical Research: Planets 116, n/a-n/a.

1239

Zysset, M. and Schindler, P. W., 1996. The proton promoted dissolution kinetics of Kmontmorillonite. Geochimica et Cosmochimica Acta 60, 921-931. 